\title{
Transcriptomic insight into salinomycin mechanisms in breast cancer cell lines: synergistic effects with dasatinib and induction of estrogen receptor $\beta$
}

Vanessa Bellat ${ }^{1}$, Alice Verchère ${ }^{2}$, Sally A. Ashe ${ }^{1}$ and Benedict Law ${ }^{1,3^{*}}$ [0

\begin{abstract}
Background: Tumors are heterogeneous in nature, composed of different cell populations with various mutations and/or phenotypes. Using a single drug to encounter cancer progression is generally ineffective. To improve the treatment outcome, multiple drugs of distinctive mechanisms but complementary anticancer activities (combination therapy) are often used to enhance antitumor efficacy and minimize the risk of acquiring drug resistance. We report here the synergistic effects of salinomycin (a polyether antibiotic) and dasatinib (a Src kinase inhibitor).

Methods: Functionally, both drugs induce cell cycle arrest, intracellular reactive oxygen species (iROS) production, and apoptosis. We rationalized that an overlapping of the drug activities should offer an enhanced anticancer effect, either through vertical inhibition of the Src-STAT3 axis or horizontal suppression of multiple pathways. We determined the toxicity induced by the drug combination and studied the kinetics of iROS production by fluorescence imaging and flow cytometry. Using genomic and proteomic techniques, including RNA-sequencing (RNA-seq), reverse transcriptionquantitative polymerase chain reaction (RT-qPCR), and Western Blot, we subsequently identified the responsible pathways that contributed to the synergistic effects of the drug combination.

Results: Compared to either drug alone, the drug combination showed enhanced potency against MDA-MB-468, MDA-MB-231, and MCF-7 human breast cancer (BC) cell lines and tumor spheroids. The drug combination induces both iROS generation and apoptosis in a time-dependent manner, following a 2-step kinetic profile. RNA-seq data revealed that the drug combination exhibited synergism through horizontal suppression of multiple pathways, possibly through a promotion of cell cycle arrest at the G1/S phase via the estrogen-mediated S-phase entry pathway, and partially via the BRCA1 and DNA damage response pathway.

(Continued on next page)
\end{abstract}

\footnotetext{
*Correspondence: sbl2004@med.cornell.edu

'Molecular Imaging Innovations Institute, Department of Radiology, Weill

Cornell Medicine, New York, NY, USA

${ }^{3}$ Lead contact, New York, USA

Full list of author information is available at the end of the article
}

(c) The Author(s). 2020 Open Access This article is licensed under a Creative Commons Attribution 4.0 International License, which permits use, sharing, adaptation, distribution and reproduction in any medium or format, as long as you give appropriate credit to the original author(s) and the source, provide a link to the Creative Commons licence, and indicate if changes were made. The images or other third party material in this article are included in the article's Creative Commons licence, unless indicated otherwise in a credit line to the material. If material is not included in the article's Creative Commons licence and your intended use is not permitted by statutory regulation or exceeds the permitted use, you will need to obtain permission directly from the copyright holder. To view a copy of this licence, visit http://creativecommons.org/licenses/by/4.0/ The Creative Commons Public Domain Dedication waiver (http://creativecommons.org/publicdomain/zero/1.0/) applies to the data made available in this article, unless otherwise stated in a credit line to the data. 


\begin{abstract}
(Continued from previous page)
Conclusion: Transcriptomic analyses revealed for the first time, that the estrogen-mediated S-phase entry pathway partially contributed to the synergistic effect of the drug combination. More importantly, our studies led to the discoveries of new potential therapeutic targets, such as E2F2, as well as a novel drug-induced targeting of estrogen receptor $\beta$ (ESR2) approach for triple-negative breast cancer treatment, currently lacking of targeted therapies.
\end{abstract}

Keywords: Synergistic drug combination, Transcriptome and proteomic analysis, Cell signaling pathway, Estrogen receptor $\beta$ (ESR2), Triple negative breast cancer (TNBC)

\section{Background}

Advances in screening, early diagnosis, and treatment have significantly reduced the mortality rate of breast cancer (BC) for the past 20 years. However, the 5-years survival rate of patients with late-stage metastatic $\mathrm{BC}$ remains low (less than 30\%) [1]. Chemotherapeutic agents and targeted therapies are the current backbone of medical management. Patients do not always respond to these treatments, as tumors can be intrinsically (de novo) resistant to the drugs. Furthermore, patients who initially responds to the treatments will likely acquire resistance over time, resulting in treatment failure or disease recurrence. To improve clinical outcomes, multiple chemotherapeutic agents (combination therapy) with distinctive drug mechanisms are used for $\mathrm{BC}$ treatments $[2,3]$. However, most clinically used drug combination regimens only increase overall response rate and prolong progression-free survival, but showed limited success for improving the patient's survival [4].

It has now become clear that tumors are heterogeneous in nature, composed of different cell populations with various mutations and/or phenotypes. Chemotherapeutic agents primarily eliminate the proliferating cells in tumors but can leave behind a small population of quiescent cancer stem cells (CSCs) that are intrinsically resistant to chemotherapy. These residual CSCs, which have metastatic potential, can remodel tumors to become more drug resistant [5]. Salinomycin (Sal) is an antibiotic isolated from Streptomyces albus that has been used as an anticoccidial agent in the poultry industries for many years (Fig. 1a). In recent years, the drug has been shown to have anti-CSCs properties [7]. Among 16,000 compounds screened as potential toxic substances against breast CSCs, Sal was able to selectively reduce the proportion of epithelial cancer stem cells by more than 100-folds compared to paclitaxel, a drug that is commonly used as a chemotherapeutic agent for BC. Early studies showed that Sal induced apoptosis by disrupting the balance of sodium and potassium ions across the mitochondrial membranes $[8,9]$. The drug induced intracellular reactive oxygen species (iROS) production, and subsequently mediated autophagy via activation of the JNK/MAPK pathway [10]. Sal also has been shown to suppress the highly conserved embryonic developmental signaling pathways, including the STAT3,
Notch, Wnt/ $\beta$-catenin, and hedgehog pathways $[11,12]$. The drug inhibited proliferation, induced apoptosis, and reduced the metastatic potential of CSCs and other cancer cells [13-18]. When used in a drug combination, Sal increased DNA damage in $\mathrm{BC}$ cells treated with doxorubicin (Dox) or etoposide [19, 20]. It also enhanced the effects of paclitaxel to induce apoptosis and prevent G2 arrest [21].

Dasatinib (Das) is a Src kinase inhibitor, and has been approved for the treatment of chronic myelogenous leukemia and acute lymphoblastic leukemia (Fig. 1a). However, its role in treating $\mathrm{BC}$ is uncertain. $\mathrm{BC}$ patients only showed limited response to monotherapy of Das [22]. Preclinical studies showed that Das inhibited BC cells by modulating epidermal growth factor receptor (EGFR) signaling [23]. Src is an upstream regulator of the STAT3, PI3K, and Ras/MAPK pathways [24]. Using Das to inhibit Src can suppress BC cell proliferation, migration, invasion, and angiogenesis [25]. Recently, Das was also shown to display anti-CSC effects. The drug reduced the percentage of aldehyde dehydrogenase 1 (ALDH1)-positive CSC populations in triple negative BC (TNBC) cell lines [26]. In this paper, we investigated the feasibility of using a combination of Sal and Das $(\mathrm{S}+\mathrm{D})$ to counter BC. Functionally, both drugs induce cell cycle arrest, iROS production, and apoptosis. We rationalized that an overlapping of the drug activities should offer an enhanced anticancer effect, either through vertical inhibition of the Src-STAT3 axis [17, 27] or horizontal suppression of multiple pathways. We studied the kinetics of iROS, and the toxicity induced by the drug combination. Using RNA-seq, we subsequently identified the responsible pathways, including the estrogen-mediated $\mathrm{S}$ phase entry pathway, that partially contributed to the synergistic effects of the drug combination. These studies led to discoveries of potential therapeutic targets, such as E2F2 as well as a novel drug-induced targeting of estrogen receptor $\beta$ (ESR2) approach, which were also described herein.

\section{Methods}

\section{Chemicals and supplies}

All reagents and resources used for this study, as well as their source and identifier, are listed in Table S1. 


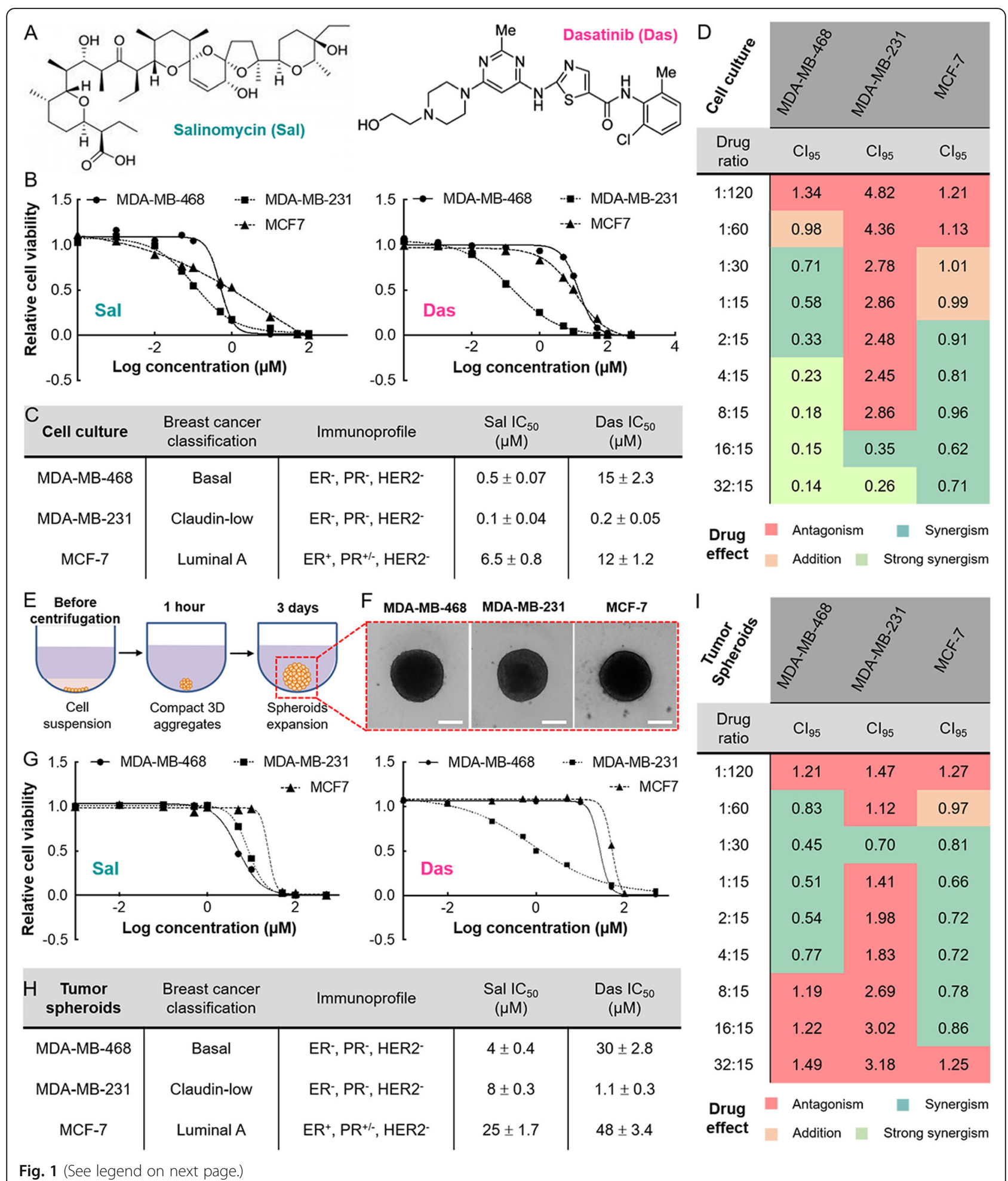


(See figure on previous page.)

Fig. 1 Evaluation of the cytotoxicity of salinomycin (Sal) and dasatinib (Das) as single drugs or a 2-drug combination on MDA-MB-468, MDA-MB231, and MCF-7 cell lines (monolayer cell culture system) and tumor spheroids. a Chemical structures of the drugs. b A comparison of the potencies of individual drugs. To measure cell viability, different human BC cell lines, cultured in monolayers, were incubated with the drugs at various concentrations for $72 \mathrm{~h}$. The results were fit into sigmoidal dose response curves for calculating the $\mathrm{I}_{50}$ values. c A table summarizing the specific $I_{50}$ values of both Sal and Das. Sal was more potent than Das regardless of the cell line tested. $\mathbf{d} A$ table summarizing the synergism of the same drug combination but different applied drug ratios of Sal and Das for treating various BC cell lines. Drug combinations had a stronger synergistic effect on MDA-MB-468, as shown by the lower $\mathrm{Cl}_{95}$ values. The $\mathrm{Cl}_{95}$ values were determined using the previously described ChouTalalay method [6]. Note that $\mathrm{Cl}_{95}$ represents the specific $\mathrm{Cl}$ value where there is a $95 \%$ cell growth inhibition. e A schematic diagram showing the method for preparing tumor spheroids. $\mathbf{f}$ Representative microscopic images of the MDA-MB-468, MDA-MB-231, and MCF-7 spheroids. Scale bar is $200 \mu \mathrm{m}$. $\mathbf{g}$ The cytotoxic effect of the drugs alone. The spheroids were treated with drugs at various concentrations for $72 \mathrm{~h}$. The results from the viability assays were fit into sigmoidal dose response curves for determining the $I C_{50}$ values. $\mathbf{h} A$ table summarizing the specific $I C_{50}$ values of Sal and Das tested on different tumor spheroids. i A comparison of the synergism of different drug combination regimens, applied concurrently at different drug ratios, for eradicating the spheroids. All the experiments were independently performed in triplicate

\section{Cell culture}

All the human $\mathrm{BC}$ cell lines were purchased directly from ATCC (Manassas, VA) in 2016. All the cell lines were cytogenetic analyzed by ATCC. Upon arrival, the cells were cultured according to the ATCC's instructions to prepare stocks for long-term cryopreservation. Prior to perform the in vitro experiments, the cells were tested for mycoplasma contamination using the MycoAlert mycoplasma detection kit (Lonza, Basel, Switzerland). To avoid genetic drift that may affect the results and reproducibility, cells were not cultured for more than 6 months. To limit any undesired fluorescence interaction during flow cytometry analysis and fluorescence imaging, cells were cultured in the absence of phenol red.

\section{Determination of the drugs potency}

To assess the cytotoxicity of the drugs alone or in combination, cells $\left(5 \times 10^{3}\right.$ cells/well) were seeded on a 96-well flat bottom plate overnight, and then treated with various concentrations of the drugs for $72 \mathrm{~h}$. After washing the cells 3 times with PBS, CellTiter-Glo 2D reagent (Promega, Madison, WI) $(50 \mu \mathrm{L})$ was added to each well. The luminescence was recorded using a microplate reader (Tecan US Inc., Morrisville, NC). The dose-response curves were plotted using GraphPad Prism 6.0 software. All data were normalized to the values obtained with untreated control cells. The half maximal inhibitory concentrations $\left(\mathrm{IC}_{50}\right)$ were calculated by fitting the data into a sigmoidal curve. The cytotoxicity of the different drug treatments was also evaluated by Trypan Blue Exclusion assay. After incubation with the drug alone or in combination for $72 \mathrm{~h}$, cells were harvested and re-suspended in an equal volume (ratio 1:1) of PBS and Trypan Blue solution (0.4\%) prior to image using EVOS microscope (Life Technology, Carlsbad, CA). Note: The drugs stock solutions were prepared in DMSO. The highest final concentration of DMSO in PBS in the samples was always lower than $0.1 \%$.

To generate the $3 \mathrm{D}$ cellular aggregates, cells $\left(1 \times 10^{4}\right.$ cells/well) suspended in medium containing $2.5 \%(\mathrm{v} / \mathrm{v})$ of Matrigel matrix basement membrane were seeded on ultra-low attachment 96-wells black with clear round bottom plates. After centrifugation $(10 \mathrm{~min}, 1000 \mathrm{rpm})$, the cells were incubated for $72 \mathrm{~h}$ to form spheroids [28]. The spheroids were then treated with various concentrations of drugs for $72 \mathrm{~h}$. The cytotoxicity was evaluated using the CellTiter Glo 3D Luminescent Assay (Promega, Madison, WI), according to the manufacturer's instructions. The images of the tumor spheroids, before and after drug treatments, were acquired using EVOS FL auto fluorescence microscope (Life Technology, Carlsbad, CA).

\section{Determination of $\mathrm{Cl}$ values}

Combination Index (CI) values were determined using the widely-used method established by Chou and Talalay [6]. To determine the CI values of a drug combination (drug $\mathrm{A}+\operatorname{drug} \mathrm{B}$ ), we first determined the $\mathrm{IC}_{50}$ value of each single drug against a specific cell line using a cell viability assay as described above. The cytotoxicity of the drug combination was then evaluated at a specific drug ratio $\left(\mathrm{IC}_{50}\right.$ of drug $\mathrm{A}$ : $\mathrm{IC}_{50}$ of drug $\mathrm{B}$ ), using different total drug concentrations. The cytotoxicity study was further extended using multiple drug ratios. The results of the cytotoxicity studies were analyzed using the Compusyn software. The software relied on the median effect equation based on the mathematical model of the physicochemical principal of the mass action law leading to the CI equation:

$$
C I=\sum_{j=1}^{n} \frac{(D)_{j}}{\left(D_{X}\right)_{j}}
$$

where $\mathrm{D}$ is the concentration of the drugs in combination to achieve $\mathrm{x} \%$ of drug effect and $\mathrm{D}_{\mathrm{x}}$ the concentration of the drugs alone to achieve the same effect. The obtained CI values allow us to assign an antagonistic $(\mathrm{CI}>1)$, an additive $(\mathrm{CI}=1)$, a synergistic $(\mathrm{CI}<1)$, or a strongly synergistic effect $(\mathrm{CI}<0.3)$ of the drug combinations. Based on the cell viability data determined in the human BC cell lines, computer-simulated plots of the CI values of the drug combination (at different drug ratios) 
versus the cellular fraction affected $(\mathrm{Fa}=1-$ the ratio of the drug-treated to the non-treated cell numbers) were then generated by the CompuSyn software.

\section{Selection of drug dosage for cellular studies}

For fair comparison, each cell line was treated with the drugs at their corresponding $\mathrm{IC}_{50}$ concentrations to induce an equipotency, for insuring each drug contributed to the similar cell killing effect. The $\mathrm{BC}$ cells were treated according to the following conditions:

\begin{tabular}{llll}
\hline $\begin{array}{l}\text { Breast cancer } \\
\text { cell lines }\end{array}$ & $\begin{array}{l}\text { Sal } \\
\text { concentration }\end{array}$ & $\begin{array}{l}\text { Das } \\
\text { concentration }\end{array}$ & $\begin{array}{l}\text { S + D } \\
\text { concentration }\end{array}$ \\
\hline MDA-MB-468 & $0.5 \mu \mathrm{M}$ & $15 \mu \mathrm{M}$ & $15.5 \mu \mathrm{M}$ \\
MDA-MB-231 & $0.1 \mu \mathrm{M}$ & $0.1 \mu \mathrm{M}$ & $0.2 \mu \mathrm{M}$ \\
MCF-7 & $6.5 \mu \mathrm{M}$ & $12 \mu \mathrm{M}$ & $18.5 \mu \mathrm{M}$ \\
\hline
\end{tabular}

Note: In the case of MDA-MB-231 cell line, the drugs used at their $\mathrm{IC}_{50}$ concentration induced an antagonistic effect (Fig. 1d). The concentration of Das was then slightly adjusted (from $0.2 \mu \mathrm{M}$ to $0.1 \mu \mathrm{M}$ ) to reach the drug ratio 16:15 for achieving a synergistic effect

\section{Cytotoxicity assays}

To investigate the cell death pathway induced by the drug combination, MDA-MB-468 cells $\left(5 \times 10^{3}\right.$ cells/well $)$ were seeded on a 96-well plate overnight, and then treated with various concentrations of $\mathrm{S}+\mathrm{D}$ (drug ratio fixed at 1:30) in the presence of ferrostatin-1 (Fer-1) and/or necrostatin1 (Nec-1) for $72 \mathrm{~h}(1 \mu \mathrm{M}$ of inhibitor content). The cytotoxicity was then evaluated using the CellTiter Glo Luminescent Assay (Promega, Madison, WI).

To determine whether Sal enhanced the targetability of TNBC by 4-hydroxytamoxifen (Tamo), MDA-MB-468 cells were concurrently treated with Sal and Tamo. Briefly, cells were seeded on 96-well plates $\left(5 \times 10^{3}\right.$ cells/well) in RPMI medium supplemented with $10 \%$ charcoal stripped FBS for overnight. The cells were then treated with PBS, Tamo $(1 \mu \mathrm{M})$, Sal $(0.5 \mu \mathrm{M})$, or the drug combination for $72 \mathrm{~h}$. The cell viability was measured as described previously. A similar experiment was performed by treating concurrently MDA-MB-468 cells with Das $(15 \mu \mathrm{M})$ and Tamo $(1 \mu \mathrm{M})$. For the sequential drug treatment experiments, cells were seeded on T25 culture flasks $\left(1 \times 10^{6}\right.$ cells/flask) overnight and then treated with PBS (control) or Sal $(0.5 \mu \mathrm{M})$ for $72 \mathrm{~h}$. Cells were then washed twice in PBS, trypsinized, and seeded on 96-wells plates $\left(3 \times 10^{3}\right.$ cells/well) immediately in the presence of various concentrations of Tamo (from 0 to $100 \mu \mathrm{M}$ ) for an additional 72 $\mathrm{h}$ period of time, prior to assess the viability.

\section{Fluorescence-activated cell sorting (FACS)}

Intracellular reactive oxygen species (iROS) were measured using a Gallios flow cytometer (Beckman Coulter Inc., Miami, FL). Cells were first seeded on T25 culture flask $\left(1 \times 10^{6}\right.$ cells/flask $)$ overnight and then treated with PBS (control) or the drugs for $6,12,24,48$, or $72 \mathrm{~h}$. Drug concentration and ratio were selected according to the $\mathrm{IC}_{50}$ values and the synergistic effect as described above. Prior to perform FACS analysis, the cells were incubated with DCFDA $(10 \mu \mathrm{M})$ for $30 \mathrm{~min}$, trypsinized, and re-suspended in PBS $(1 \mathrm{~mL})$. The analysis was performed on 10,000-gated events $\left(n=3 /\right.$ per sample) at the FL1 channel $\left(\lambda_{\text {ex }}=488 \mathrm{~nm}\right.$ and $\left.\lambda_{\mathrm{em}}=525 / 20 \mathrm{~nm}\right)$.

Annexin V (AnV)-FITC/propidium iodide (PI) double staining kit was used to evaluate the proportion of apoptotic and necrotic cells. MDA-MB-468 cells, seeded on T25 culture flask $\left(1 \times 10^{6}\right.$ cells/flask $)$, were treated with PBS (control), or the drugs alone or in combination for $72 \mathrm{~h}$. After incubation, the cells were trypsinized and then stained with AnV-FITC $(5 \mu \mathrm{L})$ and PI $(5 \mu \mathrm{L})$ for 10 min in the dark prior to FACS analysis. The apoptotic and necrotic cells were detected and quantified using the FL1 and FL2 $\left(\lambda_{\mathrm{ex}}=488 \mathrm{~nm}\right.$ and $\left.\lambda_{\mathrm{em}}=575 / 20 \mathrm{~nm}\right)$ channels. Healthy, apoptotic, necrotic, and dead cells, were identified as $\mathrm{AnV}^{-} \mathrm{PI}^{-}, \mathrm{AnV}^{+} \mathrm{PI}^{-}, \mathrm{AnV}^{-} \mathrm{PI}^{+}$, and $\mathrm{AnV}^{+} \mathrm{PI}^{+}$, respectively. The experiment was also performed after treatment of MDA-MB-468 cells with the drug combination in presence of Fer-1 and/or Nec-1 for $72 \mathrm{~h}(1 \mu \mathrm{M}$ of inhibitor content).

For determining cell-surface ESR2 level, cells were incubated with drugs alone or in combination for $72 \mathrm{~h}$. The cells were trypsinized and re-suspended in PBS $(500 \mu \mathrm{L})$, and further incubated with phycoerythrinlabeled anti-ESR2 antibody (1:100 dilution) for $30 \mathrm{~min}$ at room temperature. FACS analysis was performed at the FL2 channel.

FACS was also used for cell cycle analysis. After $72 \mathrm{~h}$ of incubation with different drug treatments (drug alone or in combination), MDA-MB-468 cells were fixed on ice with a $66 \%(\mathrm{v} / \mathrm{v})$ ethanol solution in PBS and stored at $4{ }^{\circ} \mathrm{C}$ overnight. Cells were then washed twice with PBS and re-suspended in $1 \mathrm{X}$ propidium iodide and RNase staining solution $(250 \mu \mathrm{L})$. Following $30 \mathrm{~min}$ of incubation at $37^{\circ} \mathrm{C}$, the cells were analyzed by flow cytometer. The fluorescence of propidium iodide was recorded on the FL2 channel. All the experiments were independently performed in triplicate and the data were processed using Kaluza Software 2.1.1.

\section{Fluorescence microscopy}

MDA-MB-468 or MDA-MB-231 cells $\left(5 \times 10^{3}\right.$ cells/well) were seeded on 8 -well Ibidi chamber slides overnight and then treated with PBS (control), Sal $(0.5 \mu \mathrm{M})$, Das $(15 \mu \mathrm{M})$, or the drug combination $(0.5+15 \mu \mathrm{M})$ for different time intervals $(6,12,24,48$, and $72 \mathrm{~h})$. DAPI $(9 \mu \mathrm{M})$, DCF-DA $(10 \mu \mathrm{M})$, or phycoerythrin-labeled antiestrogen receptor $\beta$ antibody (1:100 dilution) were used for staining the nucleus, the iROS, or the estrogen receptors $\beta$ (ESR2), respectively, $30 \mathrm{~min}$ before imaging. The 
cells were then washed with PBS. The fluorescence images were acquired using EVOS FL Auto Fluorescence Microscope (Life Technologies, Carlsbad, CA).

\section{RNA extraction}

Cells were seeded on a T25 culture flask $\left(1 \times 10^{6}\right.$ cells/ flask) overnight and then treated with PBS (control), drugs alone, or the drug combination for 24,48 , or $72 \mathrm{~h}$. The total RNA was extracted and purified using the RNeasy Mini kit (Qiagen, Hilden, Germany), according to the manufacturer's instructions. The final RNAs was quality-controlled using Agilent 2100 Bioanalyzer and quantified by absorbance using NanoDrop, prior to be analyzed by RNA-seq or Reverse Transcriptionquantitative Polymerase Chain Reaction (RT-qPCR).

\section{Transcriptome analysis}

Library was constructed on the purified RNAs obtained from the PBS- or drug-treated MDA-MB-468 cells (4 biological replicates per condition), using Illumina TruSeq RNA preparation kit (Illumina, San Diego, CA). The samples were sequenced using HiSeq4000 sequencer with single-end 50 bps reads. The raw sequencing reads in BCL format were processed through bcl2fastq 2.19 (Illumina) for FASTQ conversion and demultiplexing. The RNA reads were aligned and mapped to the GRCh37 human reference genome by STAR (Version2.5.2) [29]. The transcriptome reconstruction was performed by Cufflinks (Version 2.1.1). The abundance of transcripts was measured with Cufflinks in Fragments Per Kilobase of exon model per Million mapped reads (FPKM) [30]. Gene expression profiles were constructed using the DESeq2 package [31]. The resulting corrected $p$-values were calculated based on the BenjaminHochberg's method to adjust multiple testing and control the false discovery rate. Finally, Ingenuity Pathway Analysis (IPA 4.0, Ingenuity System) was used to model the differential gene expression data. The following cutoffs: adjusted $p$-value $\left(P_{\text {adj }}\right)<0.01$ and $\log 2$ fold gene expression change $>1.5$ were applied prior to performing the data analysis. The raw RNA sequencing data reported in this paper is available in the Gene Expression Omnibus (GEO) database using the accession number GSE135514 and following the link:

https://www.ncbi.nlm.nih.gov/geo/query/acc.cgi?acc= GSE135514.

\section{Reverse transcription-quantitative polymerase chain reaction ( $R T$-qPCR)}

The first-strand cDNA library was synthesized from RNA samples $(2 \mu \mathrm{g})$ using M-MLV reverse transcriptase reagent kit (Promega, Madison, WI). Quantitative realtime PCR was performed after adding the cDNA products $(1 \mu \mathrm{L})$, the corresponding gene primer set $(20 \mu \mathrm{M}$;
$1 \mu \mathrm{L})$, and SYBR Green Master Mix $(10 \mu \mathrm{L})$ to ultrapure water $(13 \mu \mathrm{L})$. Forty-five cycles of qPCR gene amplification were performed. StepOnePlus Real-Time PCR system (Applied Biosystems, Foster City, CA) was used to conform the extension step. The number of cycles $\left(C_{T}\right)$ were normalized and corrected from the house keeping gene glyceraldehyde 3-phosphate dehydrogenase (GAPD $\mathrm{H})$. Differential gene expression was expressed as a relative fold change compared to the results of the control cells treated with PBS only, using the comparative $C_{T}$ method [32]. The sequences of the primers, listed in Fig. S1, were designed using the National Center for Biotechnology Information (NCBI) software.

\section{Western blot}

MDA-MB-468 or MDA-MB-231 cells were seeded on T25 culture flask $\left(1 \times 10^{6}\right.$ cells/flask $)$ overnight and treated with PBS (control), Sal $(0.5 \mu \mathrm{M})$, Das $(15 \mu \mathrm{M})$, or the drug combination for $72 \mathrm{~h}$. Cells were then collected and lysed using RIPA buffer supplemented with $1 \%$ of phenylmethylsulfonyl fluoride $(200 \mathrm{mM}), 1 \%$ of protease inhibitor cocktail, and 1\% of sodium orthovanadate (100 mM) (Santa Cruz Biotechnology Inc., Dallas, TX). The total protein contents in cell lysates were quantified using a microBCA assay (ThermoFisher Scientific, Waltham, MA). The samples (15 $\mu \mathrm{g}$ of proteins) were separated by NuPAGE ${ }^{\mathrm{Tn}} 4-12 \%$ Bis-Tris Gel at $120 \mathrm{~V}$ and were subsequently transferred onto a polyvinylidene difluoride membrane. The membranes were blocked with $1 \mathrm{X}$ Tris buffered saline containing $0.1 \%$ of Tween $(\mathrm{v} / \mathrm{v})(\mathrm{TBST})$ and $8 \%(\mathrm{w} / \mathrm{v})$ of skimmed milk for $1 \mathrm{~h}$ at room temperature, and then incubated with primary antibodies overnight at $4{ }^{\circ} \mathrm{C}$. Membranes were washed 3 times with TBST buffer for $10 \mathrm{~min}$ and incubated with a 1:5000 dilution of the peroxidase-conjugated secondary antibody for $1 \mathrm{~h}$ at room temperature. Membranes were finally washed 3 times with TBST buffer for $10 \mathrm{~min}$. The bound secondary antibodies were detected using SuperSignal West Pico PLUS Chemiluminescent Substrate. The chemiluminescent signals were collected using the Odyssey Two-color Infrared Laser Imaging System (Licor, Lincoln, NE) and the blots were processed and cropped using Image Studio Lite 5.2 software.

\section{siRNA transfection}

To knockdown the ESR2 expression induced by the Sal treatment, MDA-MB-468 cells $\left(5 \times 10^{4}\right.$ cells/well $)$ were seeded on a 6-well plate overnight and then simultaneously treated with $\mathrm{Sal}(0.5 \mu \mathrm{M})$ and transfected with $\mathrm{Si}$ lencer Select siRNA oligonucleotides (ThermoFisher Scientific, Waltham, MA), according to the manufacturer instructions. Briefly, siRNA $(60 \mathrm{nM})$ was mixed with RNAiMAX transfection reagent in the presence of OptiMEM reduced serum medium for $5 \mathrm{~min}$ at room 
temperature. The siRNA-lipid complex and Sal were then co-incubated with the cells. An equimolar mixture of 3 different pre-designed siRNA ( $20 \mathrm{nM}$ each) targeting multiple regions of ESR2 gene (Table S1) was used to silence the estrogen expression. Silencer control 1 (ctl1) and control 2 (ctl2) siRNA, not able to interact with any human RNA, were used as negative controls. $72 \mathrm{~h}$ after siRNA transfection and drug treatment, cells were harvested prior to performing FACS analysis and cell viability assay.

\section{Results}

Sal and Das synergistically inhibited different BC cell lines and spheroids

To investigate the cytotoxicity of our drug combination $(\mathrm{S}+\mathrm{D})$, we first determined the inhibitory concentration $\left(\mathrm{IC}_{50}\right)$ values of Sal or Das on different human BC cell lines: MDA-MB-468, MDA-MB-231, and MCF-7. According to the specific $\mathrm{IC}_{50}$ values obtained, we applied different drug ratios and concentrations of the drug combination and evaluated the cytotoxic effects. Based on the cell growth inhibition, we calculated the combination index (CI) value of each dosage regimen using Compusyn software, and ultimately determined whether the drug combination was synergistic $(\mathrm{CI}<1)$, additive $(\mathrm{CI}=1)$, or antagonistic $(\mathrm{CI}>1)$ [33]. Our results showed that Sal was generally more potent than Das regardless of the cell lines tested (Fig. 1b). Among the tested cell lines, the drug was more cytotoxic against MDA-MB468 and MDA-MB-231 than MCF-7 (Fig. 1c). On the other hand, Das displayed relatively higher, micromolar range $\mathrm{IC}_{50}$ values on MDA-MB-468 and MCF-7 than MDA-MB-231. The results were expected since both MDA-MB-468 and MCF-7 are intrinsically resistant to Das [34]. We noted that for most drug combinations, the degree of synergism varied with the applied drug ratio and the tested cell lines (Fig. S2) [35-37]. Similarly, we recognized that our drug combination offered a stronger (with lower CI values) and more reliable synergistic effect on MDA-MB-468 than MCF-7. We were able to use a variety of drug ratios and concentrations against MDA-MB-468 while maintaining synergism (Fig. S3A). On the other hand, although the drug combination could synergistically inhibit MCF-7, applying certain drug ratios, such as 1:60 (Sal:Das) for treatment resulted in an undesired antagonistic effect (Fig. 1d). Interestingly, both MDA-MB-468 and MDA-MB-231 are triple negative $\mathrm{BC}$ (TNBC) cells but they responded differently to the treatment. The drug combination primarily offered an antagonistic rather than a synergistic effect with regard to MDA-MB-231 (Fig. 1d). Nevertheless, we could formulate a couple of drug ratios (16:15 and 32:15) that endorsed synergism to the 3 tested cell lines. The synergistic effect of the drug combination in each cell line was further confirmed with Trypan Blue exclusion assay (Fig. S4).

Tumor spheroids offer more accurate tumormimicking models than the traditional cell culture systems [38]. For this reason, we also evaluated the cytotoxic effects of Sal and Das using tumor spheroids. We first prepared MDA-MB-468, MDA-MB-231, and MCF7 spheroids in 96-well round-bottom plates (Figs. 1e and f). We then determined the combined cytotoxic effects of Sal and Das using the same approach we applied to our cell culture studies. In general, Sal was more potent than Das regardless of the tested spheroids. Compared to the monolayer cell culture method, we needed to apply a higher drug concentration in order to effectively eradicate the tumor spheroids, as indicated by the relatively higher $\mathrm{IC}_{50}$ values of Sal and Das (Figs. $1 \mathrm{~g}$ and h). The spheroids were significantly more resistant to the drug treatments probably due to the complexity of the 3D structure as well as the limited penetration and diffusion of the drugs into the aggregates [39]. In the cell culture studies, the drug combination showed synergism against MDA-MB-468 and MCF-7 (Fig. S3B). However, there were remarkable differences in terms of the optimal drug ratio used for treating cell lines and tumor spheroids (Figs. 1h and i). A drug ratio of 32:15 had a strong synergistic effect on MDA-MB-468 cells, but an antagonistic effect on the spheroids. In fact, the optimal drug ratio offering the strongest synergistic effect on the spheroids was 1:30. Further studies are required to investigate whether the observed discrepancies originated from differences in spheroidal penetration, and thus cellular uptakes, of the 2 drugs $[40,41]$. Overall, we demonstrated that our drug combination synergism was volatile, and strongly relied on the applied drug ratio as well as the employed cell culture and tumor spheroid models. Nevertheless, for the three BC cell lines tested, the drug combination was more effective to fragment the 3D spheroids compared to the drugs alone, as shown by the increase of the spheroids size (Fig. S5). Despite the fact that it was feasible to obtain synergism for MDA-MB-468, MDA-MB-231, and MCF-7 by finetuning the drug ratio, for ease of comparison, we chose cell cultures for further studying the synergistic mechanism of the drug combination at the molecular level.

\section{Sal and Das induced intracellular ROS (iROS) in BC cell lines in a time-dependent manner}

Sal has been shown to induce iROS production, suppress the phosphoinositide 3-kinase/protein kinase $\mathrm{B} / \mathrm{mamma-}$ lian target of rapamycin signaling pathways (PI3K/AKT/ mTOR), and cause apoptosis in prostate, brain, and breast cancer cells [42-44]. Das can also induce iROS [45]. These provided the rationale for us to investigate whether the drug combination would enhance the ROS increase in 
different human BC cell lines including MDA-MB-468, MDA-MB-231, and MCF-7, and thereby promote cytotoxicity compared to using Sal or Das alone. To test this hypothesis, we measured the kinetic changes of iROS levels in cells treated with Sal and/or Das using flow cytometry. Subsequent fluorescence-activated cell sorting (FACS) analysis revealed that there was a lag of iROS induction by Sal (Fig. 2a). The drug only began to induce iROS 12 to $24 \mathrm{~h}$ after incubation (depending on the tested cell lines). In contrast, Das rapidly induced iROS, with the level reaching a plateau after $24 \mathrm{~h}$. Despite the iROS increase after an initial transient phase, Sal was able to induce more iROS over a longer period of time $(72 \mathrm{~h})$ compared to Das $(24 \mathrm{~h})$. When the cells were concurrently treated with Sal and Das, the increase in the iROS level followed a 2-step kinetic. Presumably the 2 drugs worked together to serially induce ROS, first by Das and then by Sal. We further examined the drug-induced iROS in MDA-MB-468 cells under a fluorescence microscope, using dichlorofluorescein diacetate (DCF-DA) as the staining for visualization. Green fluorescence (iROS) began to appear in cells $24 \mathrm{~h}$ after Sal incubation (Fig. 2b). Nearly all cells treated with Das showed fluorescence signals as early as $6 \mathrm{~h}$. Compared to each drug alone, the drug combination induced more apoptosis, as shown by an increase of the apoptotic $\left(\mathrm{AnV}^{+} \mathrm{PI}^{-}\right)$and $\left(\mathrm{AnV}^{+} \mathrm{PI}^{+}\right)$cell populations accompanied with a decrease of the number of healthy cells (Figs. 2c-d and S6). AnV is known for detecting cell-surface exposure of phosphatidylserine triggered by apoptosis, ferropotosis, and/or necroptosis. Here, an addition of ferrostatin-1 (Fer-1) and/or necrostatin-1 (Nec-1) did not rescue the cell death, suggesting the cell-killing effect was unlikely from the results of ferropotosis or necroptosis (Fig. S7). Phase-contrast microscopic imaging also showed that cells treated with the drugs became unhealthy (shrank) over time (Fig. 2e). This prompted us to further investigate whether the cytotoxic effects of Sal and Das were also time-dependent. As expected, Sal showed a lag of the cytotoxic effect on MDA-MB-468 cells. A plot of the ratio of non-treated cell number to treated cell number with time revealed a $12 \mathrm{~h}$ delay of the cytotoxic effect (Fig. 2f). In contrast, Das rapidly executed its desired drug activity. Interestingly, we were able to obtain a similar iROS generation and cytotoxic profiles whether the drugs were given concurrently or sequentially with Das and then followed by Sal (Figs. $2 g$ and h). However, reversing the order of the drug incubations (Sal followed by Das) significantly weakened the iROS production as well as the cytotoxic effect during the first $24 \mathrm{~h}$ of treatment (Figs. $2 \mathrm{~g}$ and $\mathrm{h}$ ).

Sal and Das suppressed genes regulated by STAT3, Wnt/ $\beta$-catenin, and Hedgehog cell signaling pathways

The mechanisms of action of both Sal and Das are complex. It has been widely reported that these two drugs regulate multiple signaling pathways including STAT3, Wnt/ $\beta$-catenin, and hedgehog $[16-18,46,47]$. RNA-seq is a combinatorial technique that allows for quantifying global gene expression in biological samples. We employed this next generation sequencing technique to provide an initial insight into how Sal and Das alone, as well as in combination, modulated gene expression in the MDAMB-468 cell line at 24 and $72 \mathrm{~h}$. Each drug treatment displayed a unique gene expression profile. We found that the number of genes that were modulated, whether they were upregulated or downregulated, regardless of the treatments, increased over time (Table S2). Genes that were commonly regulated by the drugs alone or the drug combination increased from 18 to 480 over time (Fig. 3a). Among all the common 480 genes, 239 and 240 of them were upregulated and downregulated, respectively. (Fig. $3 \mathrm{~b})$. We then investigated the expression of the downstream targeted genes that are known to be regulated by Sal via modulations of the STAT3 (13 genes), Wnt/P-catenin (10 genes), and hedgehog (32 genes) pathways (Fig. S8). Among all these genes that we analyzed, CCND1 (which encodes cyclin D1) was the only one that has been reported to be regulated by all 3 pathways. $M Y C$ (which encodes myc) is the common targeted gene of the STAT3 and $\mathrm{Wnt} / \beta$-catenin pathways. According to the differential expression of the genes, we found that more than $40 \%$ of the genes associated with the 3 pathways were suppressed by either Sal or Das (Fig. 3b). As expected, most of the genes that were downregulated by Sal were also downregulated by Das (Fig. 3c). However, the drug combination did not seem to increase the number of the genes being modulated. Further, only 10 out of the 50 genes that we analyzed were either additively or synergistically suppressed by the drug combination (Fig. S8). Despite a predicted significant overlap in the activities of Sal and Das (Fig. 3d-e), using the drug combination only partially enhanced the suppression of certain downstream targeted genes known to be regulated by the STAT3, Wnt/B-catenin, and hedgehog pathways. Those results strongly suggested that Sal and Das might display their synergistic effect through alternative cell signaling pathways.

\section{Sal and Das exhibited synergistic effect of cell cycle arrest through a partial suppression of the estrogen-mediated S-phase entry pathway}

To investigate the synergistic mechanisms of the drug combinations, we used Ingenuity Pathway Analysis software (IPA 4.0) to identify any significant canonical pathways that were modulated by the drug treatments, based on global differential gene expression in MDAMB-468 cell lines. Our results showed that the estrogenmediated S-phase entry pathway was the most significant one modulated by Sal after $72 \mathrm{~h}$ of treatment (Fig. 4a). The pathway is composed of 26 genes/proteins 


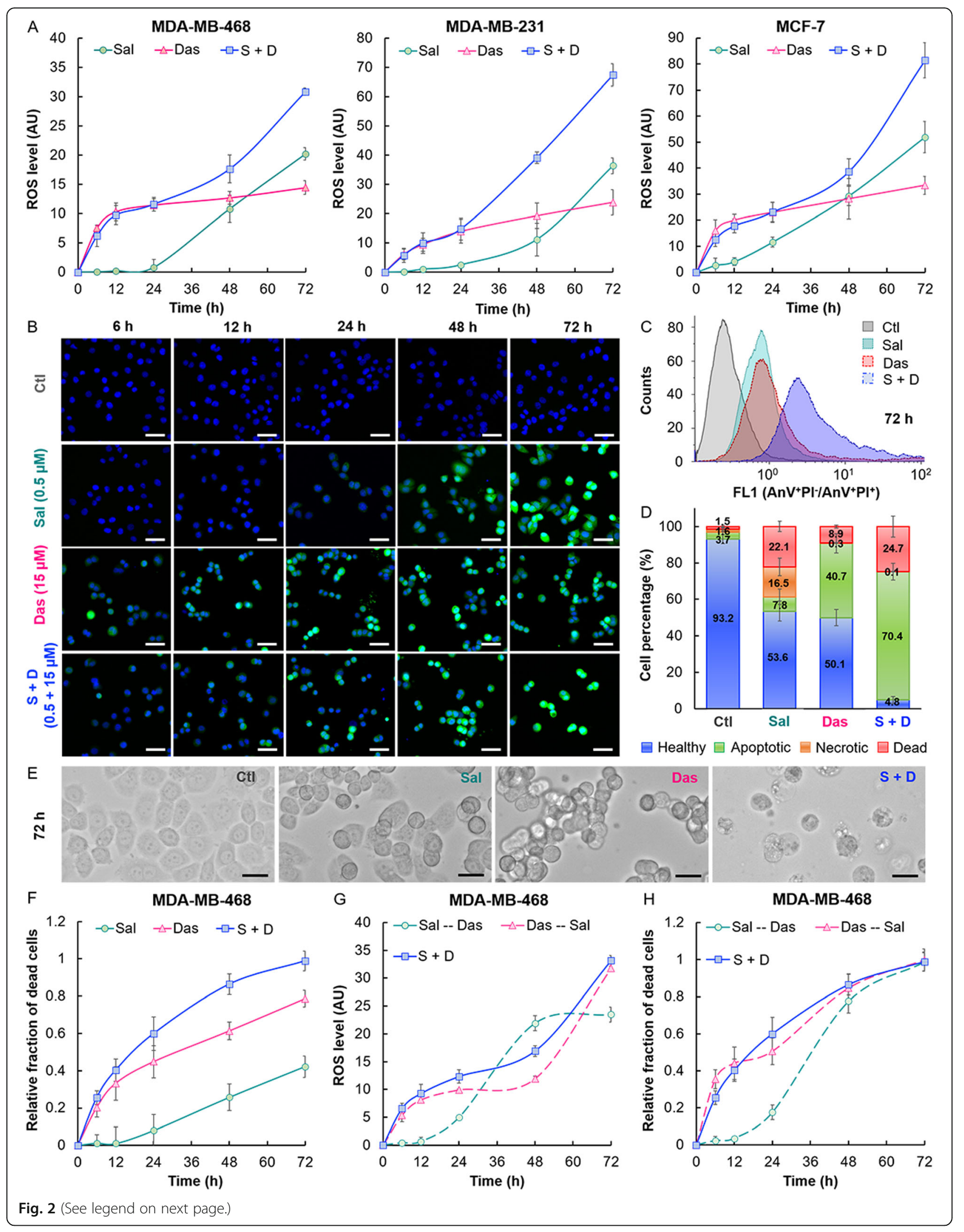


(See figure on previous page.)

Fig. 2 The drug combination enriched iROS production and promoted cytotoxicity compared to Sal or Das alone, in a time-dependent manner. a Plots of the drug-induced iROS level versus time. The induction of iROS by the drug combination followed a 2-step kinetic. MDA-MB-468, MDAMB-231, and MCF-7 cell lines were treated with individual drugs (at the corresponding $I C_{50}$ concentration (Fig. 1C)) or the 2-drug mixture prior to incubation with DCF-DA for FACS analysis of the iROS level. The mean fluorescence was calculated by comparison with PBS-treated cells (control). b Fluorescence microscopy confirmed that the drug-induced iROS increase in treated MDA-MB-468 cells was time-dependent. Prior to imaging, the cells were treated with DCF-DA and DAPI for staining the iROS (green) and nucleus (blue), respectively. Scale bar is $45 \mu \mathrm{m}$. c A flow cytometry graph showing the increase of the apoptotic $\left(\mathrm{AnV}^{+} \mathrm{PI}^{-}\right) / \mathrm{dead}\left(\mathrm{AnV}^{+} \mathrm{PI}^{+}\right)$cell population in response to the drug treatments. MDA-MB-468 cells were incubated with Sal $(0.5 \mu \mathrm{M})$, Das $(15 \mu \mathrm{M})$ or the 2-drugs combination for $72 \mathrm{~h}$ prior to staining with AnV-FITC and PI for FACS analysis. d Graph bars showing the percentage of healthy, apoptotic, necrotic, and dead cells following treatment with PBS (control) Sal, Das, or S + D for 72 h (see Fig. $\mathbf{S 6}$ for detailed quantification of the cell populations). e Representative microscopic images of MDA-MB-468 cells $72 \mathrm{~h}$ after drug incubation. Scale bar is $25 \mu \mathrm{m}$. $\mathbf{f}$ Cell viability assay showed that the cytotoxicities of Sal and Das alone or the drug combination were also timedependent. $\mathbf{g}$-h Comparing the cytotoxicities of the same drug combination applied sequentially and concurrently for treating MDA-MB-468 cell line. The cells were treated sequentially with Sal and followed by Das (Sal--Das) or Das and then Sal (Das--Sal), or concurrently with Sal and Das $(S+D)$. The concentration of Sal and Das used in this study was 0.5 and $15 \mu \mathrm{M}$, respectively. Plots showing the changes in the (g) iROS level and (h) ratio of the drug-treated to non-treated cell numbers over time. All the experiments were independently performed in triplicate

working together as gatekeepers for G1/S phase progression (Fig. 4b). Sal modulated $54 \%$ of the genes (14 out of 26 genes), with 12 of them downregulated. The Salinduced gene expression changes were time-dependent, as there was a limited transcriptomic change when the cells were treated with Sal for only $24 \mathrm{~h}$ (Fig. S9). On the other hand, Das could only suppress 5 of the genes associated with the estrogen-mediated S-phase entry pathway, which included CCND1, CDC25A, CDK2, $E 2 F 2$, and $M Y C$ (Fig. 4c). CCND1 and $M Y C$ are the downstream targeted genes of the STAT3, Wnt/ $\beta$-catenin, and/or hedgehog pathways (see the above section). We also discovered that either Sal or Das was able to suppress E2F2. Most importantly, following the 2-drugs combination treatment, the proportion of genes modulated in the estrogen-mediated S-phase entry pathway increased from 54 to $58 \%$ compared to Sal monotherapy (Fig. 4a). This strongly suggests that the modulation of the estrogen-mediated S-phase entry pathway is mainly induced by Sal but the addition of Das further contributed to its inhibition, as Das enhanced the suppressions of most genes (10 out of 12) found downregulated by Sal (Fig. 4c). Interestingly, although Sal suppressed 54\% of the genes associated with the estrogen-mediated S-phase entry pathway, it upregulated estrogen receptor (ER). It is noted that there are two classes of ER: ER $\alpha$ and ER $\beta$. The tumors of ER-positive breast cancer patients are overexpressed with ER $\alpha$. Here, Sal, Das, or the drug combination did not alter the ER $\alpha$ expression in MDAMB-468. In fact, ER $\beta$ was found to be upregulated by Sal, but not Das. Further study is needed to investigate how Sal regulates ER $\beta$.

We further validated the RNA-seq data using RT-qPCR analysis of the gene expressions that are associated with the estrogen-mediated S-phase entry pathway (Figs. 5a and S10). There was a linear relationship $\left(R^{2}>0.96\right)$ between the 2 methods used for determining differential gene expression induced by the drug combination (Figs. $5 \mathrm{~b}$ and S11). Using RT-qPCR, we also demonstrated that the drug combination synergistically suppressed the estrogen-mediated S-phase entry pathway in MDA-MB231 and MCF-7, in addition to MDA-MB-468 cell lines (Figs. 5a and S12). As mentioned above, this pathway controls the transition from $\mathrm{G} 1$ to $\mathrm{S}$ phase in cell cycle. An inhibition of the pathway can induce cell cycle arrest [48]. To confirm this effect, MDA-MB-468 cells were treated with the drugs alone or in combination for $72 \mathrm{~h}$ and were then analyzed by flow cytometry. As expected, Sal decreased the percentage of cell population in the $\mathrm{S}$ phase from 27.3\% (non-treated control) to 19.3\% (Figs. 5c and d). The drug combination further enhanced such a decrease to $11.5 \%$, which accompanied an increase of the cell population at the G1 phase from $43.2 \%$ (control) to $68.5 \%$. Overall, our results suggested that the synergistic effect of the drug combination was possibly achieved through promotion of the cell cycle arrest via partial inhibition of the estrogen-mediated S-phase entry pathway. This was further supported by western blot analysis of the translational products (protein expression). Either Sal or Das downregulated cyclin D1 (CCND1), cyclin E2 (CCNE2), and E2F2 (Figs. 5e-f and S13). Importantly, the drug combination enhanced the suppressions of cyclin D1 and E2F2.

\section{The therapeutic implication of Sal-induced ESR2 expression}

Although the IPA software identified the estrogenmediated S-phase entry pathway as the main pathway modulated by the drug combination, Sal surprisingly induced rather than suppressed ESR2 expression (Figs. 4b and c). Western blot analysis showed an increase in the translational product, estrogen receptor $\beta$ (ESR2), in MDA-MB-468 treated with Sal (Figs. 5e and f). We further confirmed the such a Sal-induced ESR2 with FACS analysis and microscopic study. Compared to the non-treated cells, MDA-MB-468 treated with Sal showed an approximately 10-fold increase of the fluorescence signal with fluorophore-conjugated ESR2 antibody staining (Figs. 6a 


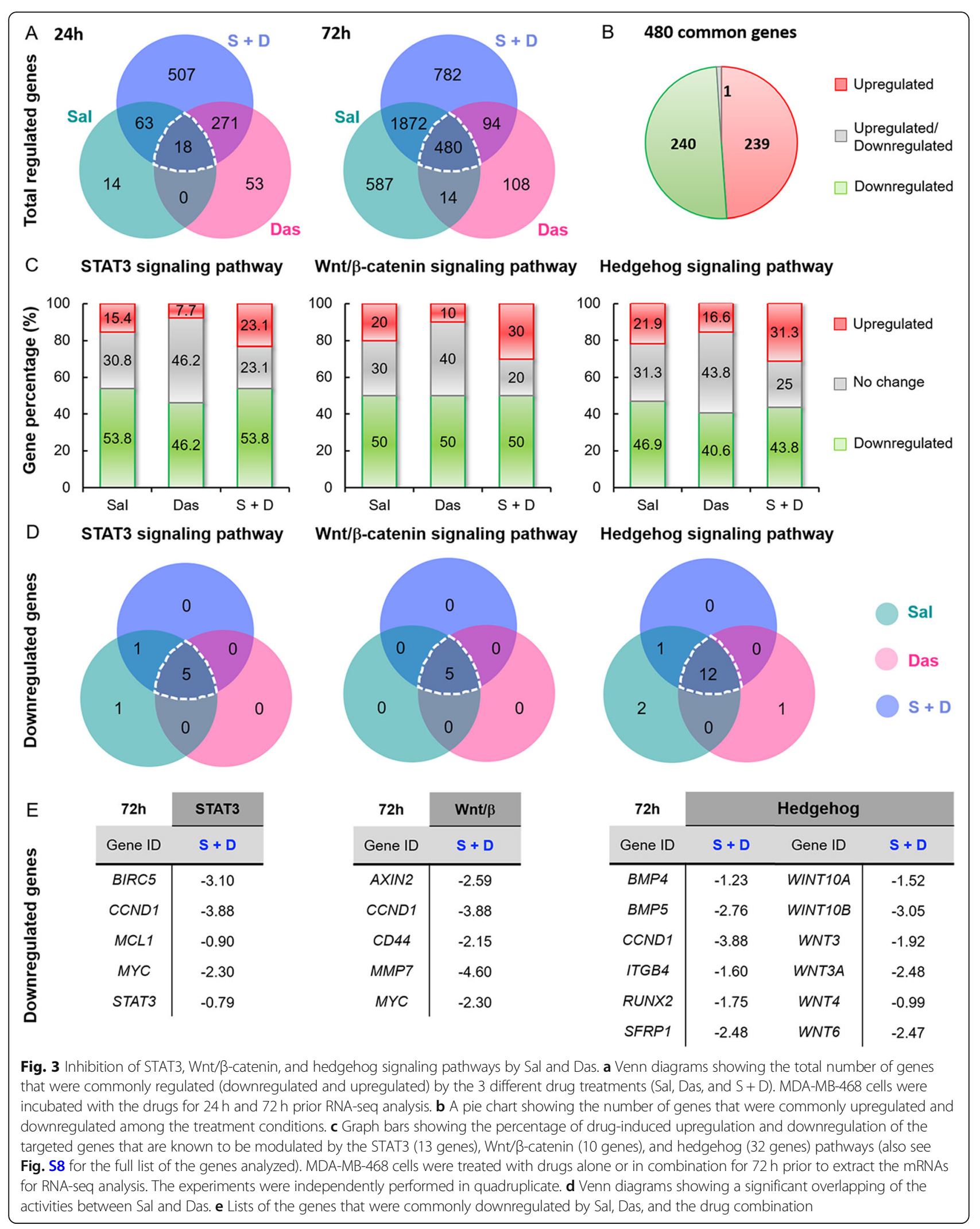




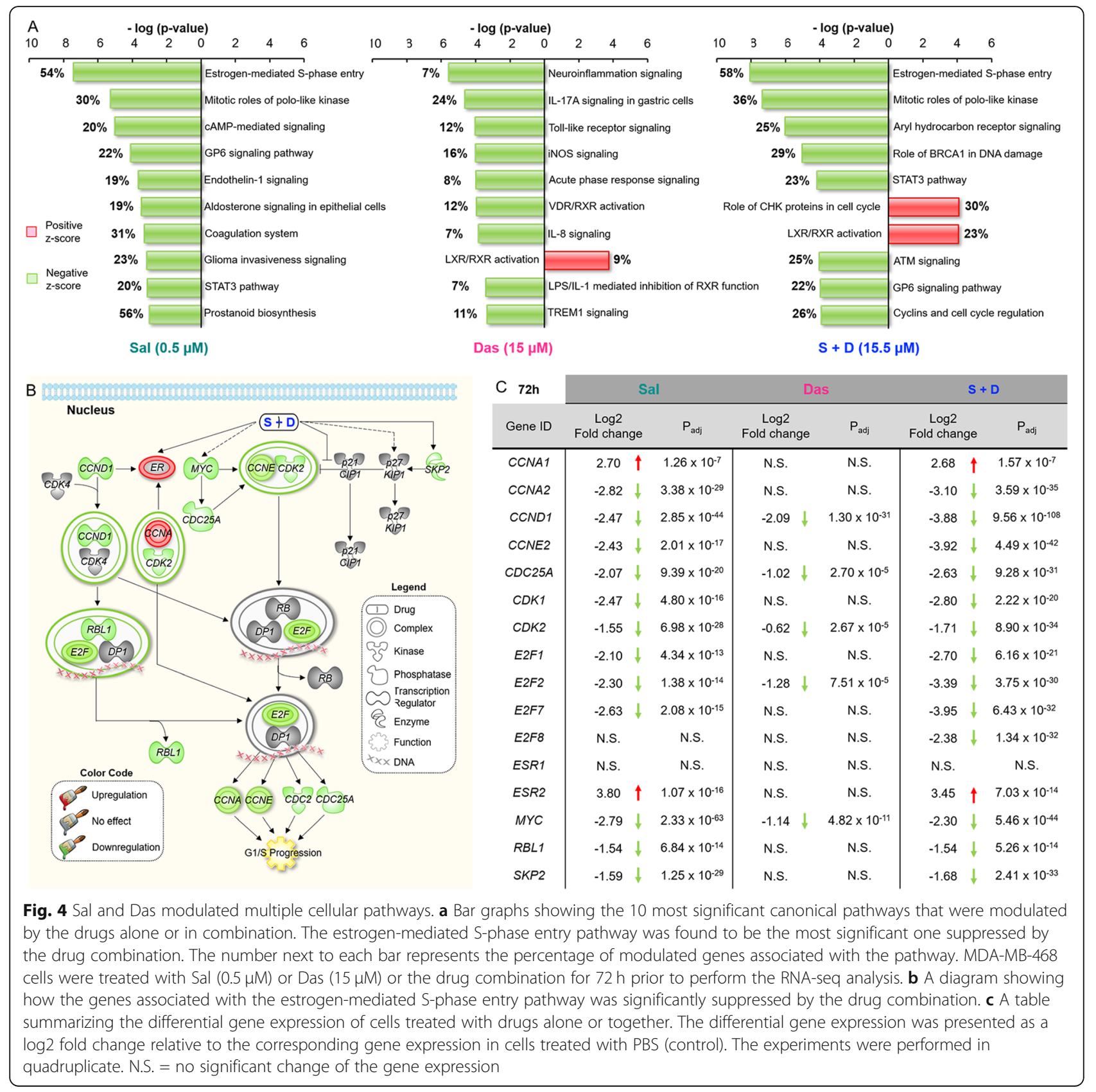

and b). The drug-induced ESR2 could be knocked down by siRNA (Fig. 6c). Similarly, we also observed an increase of ESR2 expression in MDA-MB-231 cells treated with Sal (Fig. S14).

Tamoxifen has been shown to increase the interaction between ESR2 and mutant TP53, and leading to a reactivation of TP73 and apoptosis [49]. The ability of Sal to induce ESR2 in MDA-MB-468 and MDA-MB-231 suggested that there is potential of a new drug-induced targeting of ESR2 approach for BC. 4-hydroxytamoxifen (Tamo) is an active metabolite of tamoxifen known to strongly bind estrogen receptors (Fig. S15A). Here, we applied $1 \mu \mathrm{M}$ of Tamo for investigating whether the drug could effectively target Sal-induced TNBC (Fig. 6d). At this drug concentration, Tamo was non-toxic to MDAMB-468 since the cells only displayed a very low level of ESR2 (Fig. 5e). Using Sal $(0.5 \mu \mathrm{M})$ and Tamo concurrently reduced the cell viability to $10 \%$ compared to the cells treated with PBS (100\%). The drug combination was more cytotoxic than the single drug treatment, as Sal alone could only reduce the cell viability to $50 \%$. On the other hand, Das did not induce ESR2 expression and thus its cytotoxicity was not being enhanced by Tamo (Fig. S15B). A plot of the CI values of the drug 


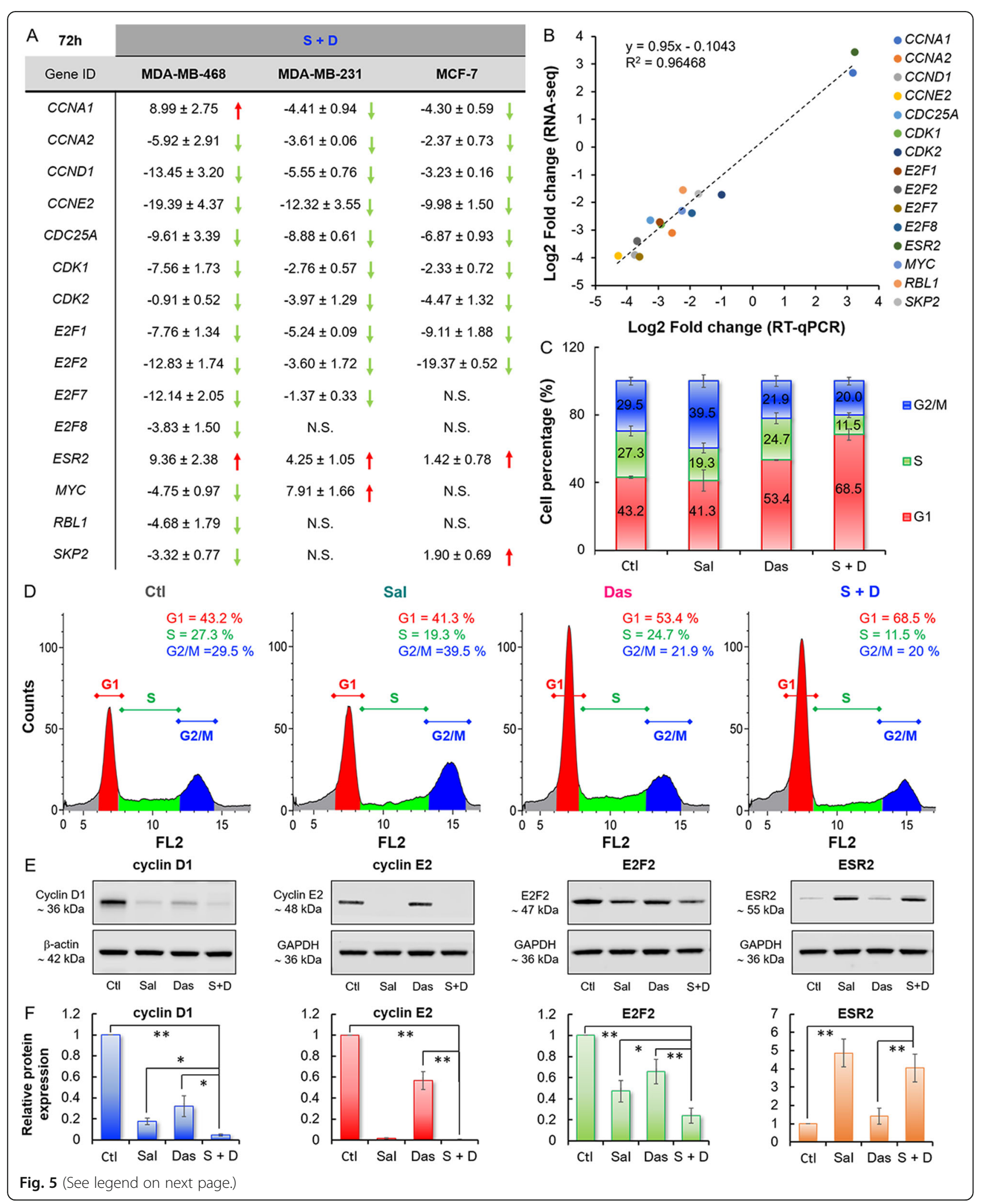


(See figure on previous page.)

Fig. 5 The drug combination enhanced cell cycle arrest at the G1/S phase. a A table summarizing the changes in the expression of genes (induced by the drug combination) associated with the estrogen-mediated S-phase entry pathway. The mRNAs were extracted from different BC cell lines $72 \mathrm{~h}$ after treatment with the drug combination prior to RT-qPCR analysis. $\mathbf{b}$ A correlation plot of the differential gene expression levels in MDA-MB-468 cell lines determined using RNA-seq and RT-GPCR methods. $\mathbf{c}$ Plots of cell counts versus the propidium iodide fluorescence (FL2). MDA-MB-468 cells were treated with PBS (control), Sal $(0.5 \mu \mathrm{M})$, Das $(15 \mu \mathrm{M})$, or the drug combination for $72 \mathrm{~h}$, fixed in ethanol, and incubated with propidium iodide and RNase staining solution prior to FACS analysis. All the experiments were performed in triplicate. $\mathbf{d}$ Graph bars showing the percentage of cells at G1, S, and G2/M phases after the drug treatments. e The drug combination also modulated the estrogen-mediated Sphase entry pathway at the translational level. Western Blot analysis of cyclin D1, cyclin E2, E2F2, and ESR2 protein expression in MDA-MB-468 cells after exposure to the drugs alone or in combination for $72 \mathrm{~h}$. GAPDH and $\beta$-actin were used as loading controls based on the molecular weight of the proteins of interest. The blots were processed and cropped using Image Studio Lite 5.2 software. Full-length blots are available Fig. S13. f Graph bar showing the expression level of each selected protein. The relative protein expression levels were quantified using Image Studio software and normalized to the control cells treated with PBS. All the experiments were performed in triplicate. Data were presented as mean \pm standard deviation (SD) and statistical differences were analyzed using Student's t-test ${ }^{*} P<0.05,{ }^{* *} P<0.01$ )

combination versus cellular fraction affected (Fa) revealed a strongly synergistic effect of the two drugs (Fig. $6 e)$. Such an enhanced cytotoxicity was attributed to the induction of ESR2 by Sal, as Tamo could no longer enhance the toxicity of Sal when the ESR2 expression was knocked down by siRNA (Fig. 6d). To demonstrate that Sal-induced ESR2 sensitized the targetability of TNBC cells by Tamo, we first pre-treated MDA-MB-468 with Sal and followed by Tamo treatment. Cytotoxicity assay revealed that Tamo was more effective on cells pretreated with Sal than PBS, with $\mathrm{IC}_{50}$ values of 2.1 versus $6.9 \mu \mathrm{M}$ (Fig. 6f). Overall, our results showed that Salinduced ESR2 expression worked complimentarily with Tamo to promote an anticancer effect, suggesting a novel targeted treatment approach for BC lacking of clinically-relevant biomarker, such as TNBC.

\section{Discussion}

A recent study supported the benefits of targeting SrcSTAT3, which showed that Das and CYT387 (JAK/ STAT inhibitor) together synergistically reduced proliferation and induced apoptosis of renal cell carcinoma [50]. In the present study, we demonstrated that Sal and Das (Src inhibitor) together synergistically inhibited the growth of MCF-7 and MDA-MB-468 cell lines. However, similar to other reported drug combinations [3537], the degree of synergism relied on the applied drug ratio, and was also cell line-dependent. ROS are central signaling molecules that regulate cell growth and survival. We showed that Das rapidly elevated the iROS level inside BC cells. In contrast, cells treated with Sal followed an initial transient phase- a lag of iROS generation, depending on the treated cell types. The delayed iROS production held back the cytotoxic effect of Sal. This was supported by a previous report that Salinduced iROS act upstream of the PI3K/AKT/mTOR signaling pathway [44]. The drug was shown to decrease phosphorylation of AKT and mTOR, and led to apoptosis in a time- and concentration-dependent manner. The difference in the kinetics of drug-induced iROS between Sal and Das resulted in a 2 -step kinetic profile when they were concurrently used in a combination setting. Nevertheless, the drug combination generated more iROS and displayed enhanced cytotoxicity compared to Sal or Das alone.

In terms of drug mechanism, Sal inhibits STAT3, Wnt/ $\beta$-catenin, and hedgehog cell signaling pathways $[16-18,46,47]$. These pathways are composed of multiple protein kinases, leading to overall activities that are often controlled by a balance (ratio) between the phosphorylated and non-phosphorylated forms of the enzymes rather than the actual expression levels. Therefore, we applied an indirect approach to investigate how Sal and Das regulated the activities of these pathways: we simultaneously determined the differential expression of the downstream targeted genes using RNA-seq. The Sal-induced inhibitory effect resulted in many of the targeted genes involved in the 3 pathways being downregulated. These genes were also found suppressed by Das [50-52]. Despite the fact that we observed an overlapping of the drug-induced transcriptomic changes between Sal and Das, the drug combination did not offer a superior advantage in terms of enhancing gene regulations, except in the cases of certain genes such as BIRC5, $C C N D 1$, and $W n t 3 A$, which were synergistically suppressed. This suggested that the 3 pathways might only partially contributed to the enhanced cytotoxic effect. In fact, IPA software showed that Sal significantly suppressed the estrogen-mediated S-phase entry pathway. This pathway controls G1/S phase transition. Sal induces cell cycle arrest [53]. Fourteen out of 26 (54\%) of the genes associated with the pathway were modulated by the drug, with 12 of them being downregulated. Among them, CCND1 is a common downstream transcriptional target of the STAT3, Wnt/ $\beta$-catenin, and hedgehog pathways. A suppression of SKP2 (encoding Skp2) was expected here given that $\mathrm{Sal}$ is known to inhibit the transcription of SKP2 [13]. For the first time, we discovered that Sal also downregulated E2F1, E2F2, and E2F7. These genes belong to a family of transcription factors, 


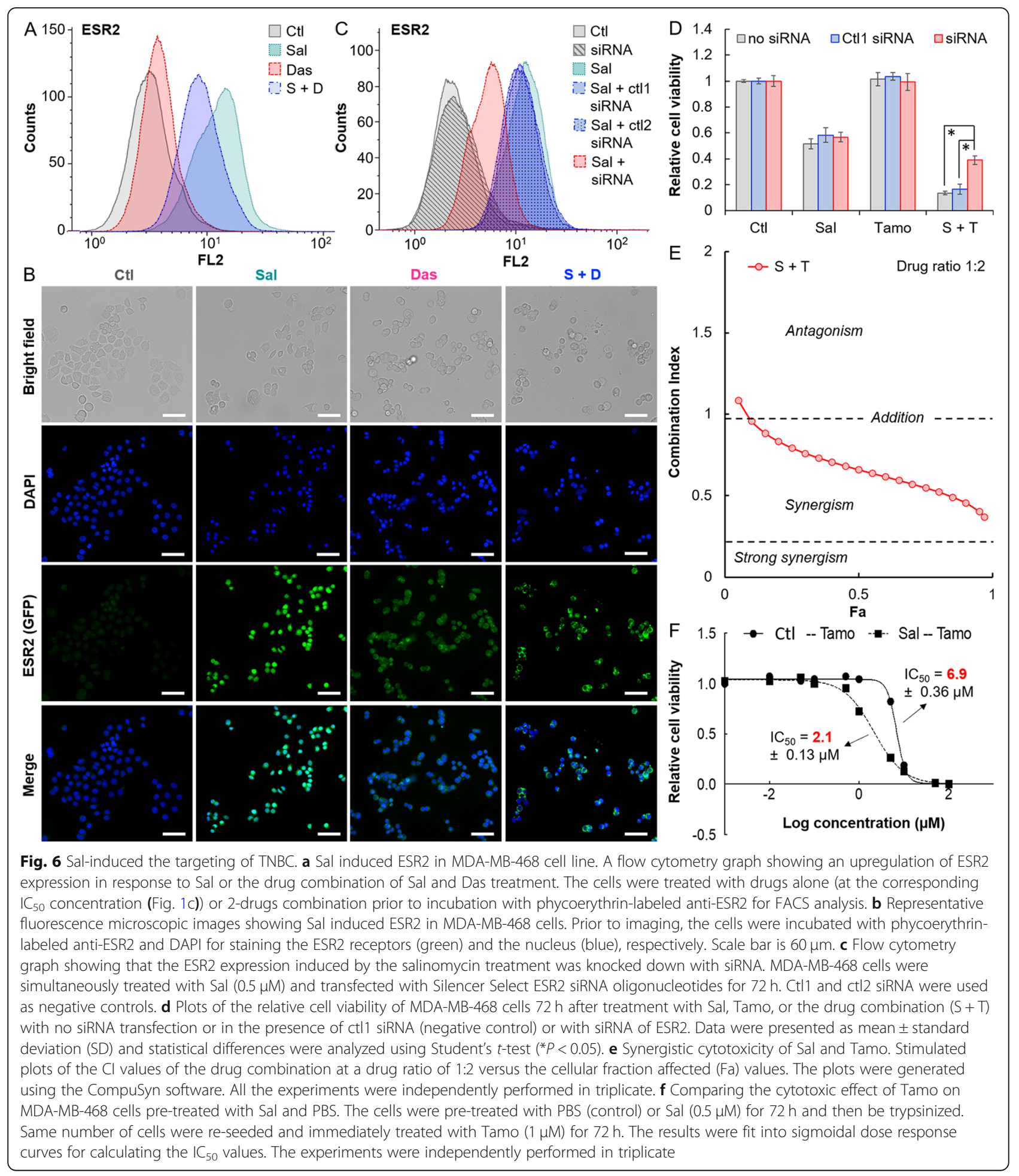

E2F, that is functionally divided into activators (E2F1E2F3) and inhibitors (E2F4-E2F8) [54, 55]. The exact roles of the individual E2F homologues in cancer progression are not fully understood. E2F1-E2F3 are the central regulators of cell cycle [56]. The activities are negatively regulated via binding with retinoblastoma-like
1 protein (RB; encoded by RBL1). During the late G1 phase of the cell cycle, cyclin-dependent kinase complexes (cyclin D/CDK4) phosphorylate RB to release the active E2F. This promotes the transcriptions of multiple targeted genes required for proceeding to the S-phase, including those that were downregulated by Sal 
(CCNA2, CCNE2, CDC2, and CDC25A) in the present study. Das induces apoptosis and cell cycle arrest via modulations of EGFR/MAPK/AKT signaling pathways [23]. This might explain why the drug could also suppress $C C N D 1, C D C 25 A, C D K 2, E 2 F 2$, and $M Y C$ here. When used with Sal, Das enhanced the inhibition of the estrogen-mediated S-phase entry pathway. This was confirmed by RT-qPCR for mRNA expression and western blot for the protein levels. Using RT-qPCR, we further showed that the drug combination also effectively downregulated the pathway in MCF-7 and MDA-MB-231 cell lines. An inhibition of the estrogen-mediated S-phase entry pathway by the drug combination led to a more severe cell cycle arrest compared to Sal or Das, as shown in our cell-cycle assays.

ESR2 was only discovered recently, and the exact role of ESR2 remains elusive. The receptor is evenly distributed among the four molecular BC subtypes, including TNBC [57, 58]. Early studies showed that ESR2 exhibited anti-tumor properties. Introducing exogenous ESR2 cDNA to MDA-MB-231 inhibited the cell proliferation [59]. Following to treatments with ESR2 agonists (ERB-041 and WAY200070), both MDA-MB-231 and HS578T decreased the invasiveness [60]. In another study, ESR2 was shown to bind and oppose the transcriptional activity of mutant PT53, and led to an inhibition of epithelial-to-mesenchymal transition in MDAMB-231 [61]. On the other hand, many studies conversely reported that ESR2 was in fact pro-tumorigenic. Using shRNA to silence ESR2 reduced TNBC cell proliferation [62]. An activation of ESR2 with diarylpropionitrile, a specific agonist, increased the proliferation and migration of TNBC cells [57]. Clinically, the role of ESR2 is also controversial. The presence of ESR2 in BC tumor was associated with the levels of proliferation markers such as Ki67 [63], but a high expression of the receptor was shown to improve the overall survival of $\mathrm{BC}$ patients treated with tamoxifen [64, 65]. In TNBC, ESR2 expression was found correlated with a lower overall relapse-free survival [57]. It has now become more clear that ESR2 has a bi-faceted role. Whether ESR2 displayed a pro- or anti-proliferative effect depended on the binding to the wild type or the mutated form of P53, respectively [49]. The same study also revealed that Tamo, a competitive ESR receptor, increased the interaction between ESR2 and mutant TP53 (found in MDA-MB-468 and MDA-MB-231 cell lines), and leading to a reactivation of TP73 and apoptosis [49]. In the present study, we discovered a novel mechanism of Sal to induce ESR2 expression in TNBC cell lines. Using a drug combination of Sal and Tamo could produce a synergistic anti-cancer effect against both MDA-MB-468 and MDA-MB-231 cell lines, suggesting a novel drug-induced targeting approach for TNBC treatment.
Although IPA identified the estrogen-mediated Sphase entry pathway was the most significant pathway modulated (suppressed) by our drug combination, we could not rule out the possibility that other pathways were involved in the synergistic effect. A recent metaanalysis of RNA-seq data from multiple studies revealed that the BRCA1 and DNA damage response pathway was upregulated in breast tumors compared to healthy breast tissues, in addition to the estrogen-mediated Sphase entry pathway [66]. In the present study, IPA identified the BRCA1 and DNA damage response pathway as the fourth most significant pathway modulated by the drug combination (Fig. 4a). The transcription of $B R C A 1$ is regulated by an upstream early growth response protein 1 (EGR1; encoded by EGR1) through binding to the EGR1-binding sequences within the enhancer region of BRCA1 [67]. Either Sal and Das alone or in combination suppressed EGR1 (data not shown). Functionally, BRCA1 is a central mediator that controls the activities of multiple DNA repair and checkpoint pathways [68]. The protein forms a heterodimer with BRCA associated RING domain protein 1 (BARD1), which is essential for interacting with different transcription regulators to form 3 distinct complexes: BRCA1 A, B, and C complexes (Figs. 7 and S16) [69]. Complex A is involved in DNA repair via homologous recombination. Complexes B and $\mathrm{C}$ regulate cell cycle checkpoint, in addition to repairing damaged DNA. An in-depth analysis of our RNA-seq data uncovered that Sal and Das together synergistically inhibited the BRCA1 and DNA damage response pathway (Figs. 7 and S16). Interestingly, the drug combination selectively impaired the pathway predominantly via an inhibition of the BRCA1 $\mathrm{B}$ complex. This was evidenced by the downregulation of a majority of the genes associated with the complex formation, including $B A C H 1$ (encodes BRCA1 interacting protein $\mathrm{C}$-terminal helicase), and $B L M$ (encodes blood syndrome RecQ like helicase), and RFC (replication factor $C$ ). Further studies are needed to confirm the drug inhibitory effects at the protein translational level as well as the therapeutic benefits of targeting BRCA1 B complex and causing cell cycle arrest. Finally, a recent study identified nucleolin as the functional binding target of Sal. The drug inhibited the transcription of the nucleolin gene $(N C L)$ and led to a suppression of downstream CD34 gene expression [70], which was also shown in our RNA-seq data.

\section{Conclusion}

In conclusion, we employed RNA-seq to investigate the global transcriptomic changes induced by Sal and Das separately and together in the human TNBC cell line MDA-MB-468. An advantage of using RNA-seq is that it allowed us to revisit the mechanisms of action and 


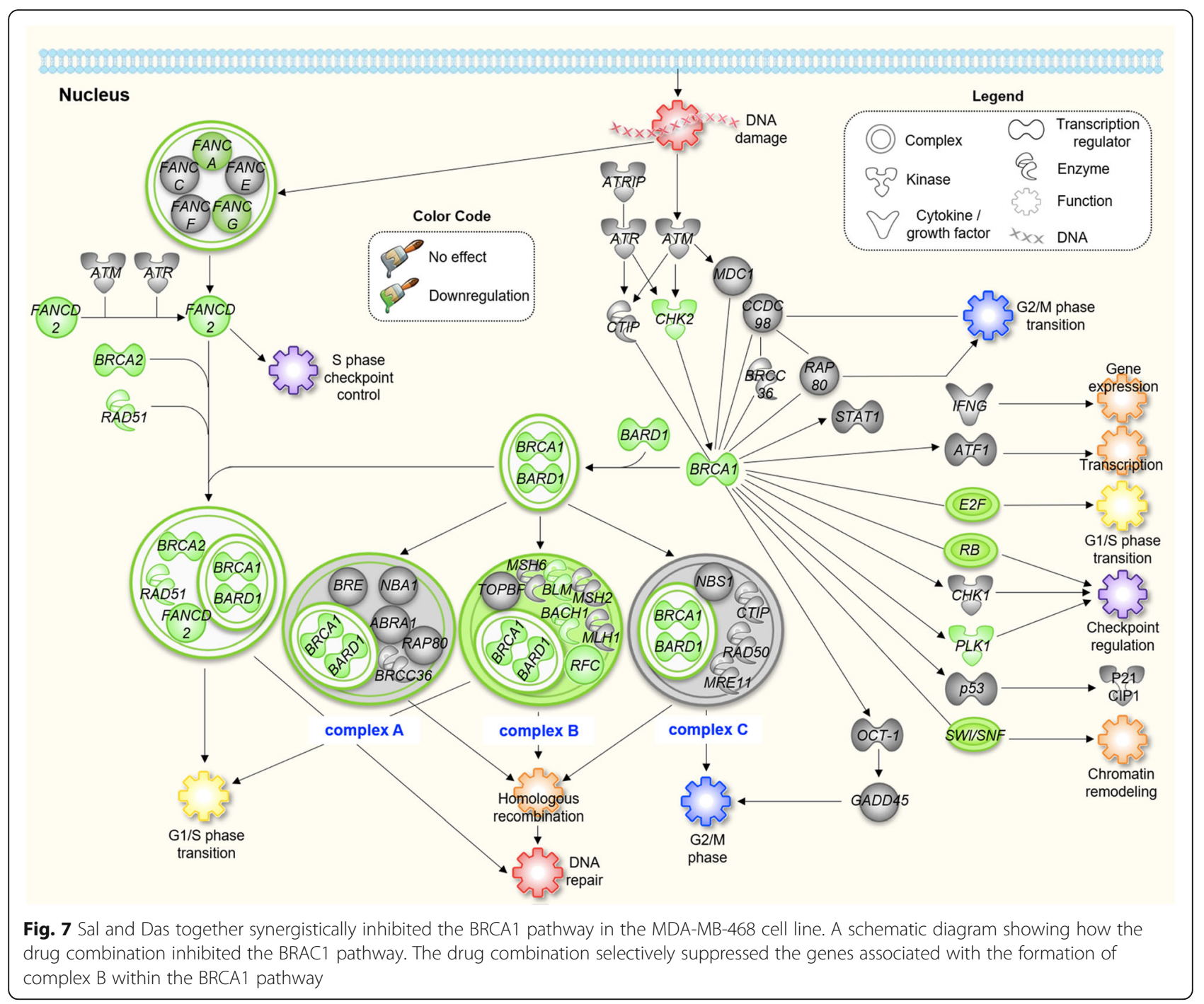

identify new therapeutic targets. Consistent with the literatures, Sal and Das suppressed known genes, including BIRC5, CCND1, MCL1, MYC, AXIN2, MMP7, BMP4, $B M P 5$, and many others that are regulated by the STAT3, Wnt/ß-catenin, and hedgehog cell signaling pathways. However, the drug combination did not seem to enhance the suppression of these genes. The drug combination exhibited synergism through horizontal suppression of multiple pathways, leading to a promotion of cell cycle arrest at the G1/S phase partially via the estrogen-mediated S-phase entry pathway, as well as the BRCA1 and DNA damage response pathway. Our studies demonstrated, for the first time, that Sal could downregulate $E 2 F 2$. We also discovered a novel mechanism of the drug to upregulate ESR2. Currently, there is a lack of targeted therapy for TNBC. Such a drug-induced ESR2 expression might lead to a novel targeting approach by using a combination of Sal and Tamo for TNBC treatment. However, further studies are required to address the in vivo efficacy and to repurpose/restratify the clinical role endocrine (hormone) therapy for $\mathrm{BC}$ treatment.

Many biological processes are regulated by enzyme activities, such as phosphorylation (by kinases) and proteolysis (by proteases), rather than actual gene and protein expression. RNA-seq can provide a comprehensive insight into drug actions, but the information obtained was limited to the transcriptomic level. Further, not all gene expression will translate into proteins leading to quantitative and qualitative divergences between genomic/transcriptomic modulations and their protein counterparts [71]. A recent retrospective and integrated genomic, transcriptomic, and protein analysis identified the transcript and protein products of SPAG5 as biomarkers of chemotherapy sensitivity in estrogen receptor-negative $\mathrm{BC}$ [72]. Another study exploited protein expression from reverse-phase protein assay and RNA-seq data to study the functional consequences of 
PIK3CA mutation leading to the tumorigenesis of $\mathrm{HER}^{+} / \mathrm{ER}^{+} \mathrm{BC}$ [73]. We believe that using a combined multi-omics approach to study drug mechanisms will allow us to identify more specific disease-relevant biomarkers for precision treatment of $\mathrm{BC}$, as well as other cancers in the future.

\section{Supplementary information}

Supplementary information accompanies this paper at https://doi.org/10 1186/s12885-020-07134-3.

Additional file 1 Table S1: Table summarizing the source and the identifier of the reagents and resources used for this study.

Additional file $\mathbf{2}$ Table S2: Table summarizing the number of genes upregulated and downregulated by different drug treatments. MDA-MB468 cells were treated with the Sal or Das alone, or the drug combination $(\mathrm{S}+\mathrm{D})$ for $24 \mathrm{~h}$ and $72 \mathrm{~h}$ prior to extract the mRNAs for RNA-seq analysis. The experiments were independently performed in quadruplicate.

Additional file 3 Figure S1: Human primer sequences used for the RTQPCR analysis.

Additional file 4 Figure S2: Examples of drug combination synergism relying on drug ratio. (A) Chemical structure of doxorubicin (Dox). (B) Cell viability assay of Dox against different human BC cell lines (MDA-MB-468, MDA-MB-231, and MCF-7). The cell viability was first measured $72 \mathrm{~h}$ after the drug incubations. (C) The results were then fit into sigmoidal dose response curves for calculating the $I C_{50}$ values. A table summarizing the $\mathrm{IC}_{50}$ values of Dox determined using different cell lines. (D) Tables showing the $\mathrm{Cl}$ values of 2-drug combinations of Dox and Das (Dox + Das) or Sal (Dox + Sal) determined at various drug ratios in MDA-MB-468 cell line. The $\mathrm{Cl}$ values were determined $72 \mathrm{~h}$ after the drug incubations according to the previously described Chou-Talalay method [33]. The $\mathrm{Cl}_{95}$ represents the specific $\mathrm{Cl}$ value at $95 \%$ of cell growth inhibition. Inset: $\mathrm{S}=$ synergistic effect. SS = strongly synergistic effect. (E) Representative simulated plots of the $\mathrm{Cl}$ values of the drug combinations Dox + Das and Dox + Sal (at different drug ratios) versus the cellular fraction affected ( $\mathrm{Fa}$ ) values. The plots were generated using CompuSyn software. All the experiments were independently performed in triplicate.

Additional file $\mathbf{5}$ Figure S3: Representative computer-simulated plots of the $\mathrm{Cl}$ values of the drug combination (at different drug ratios) versus the cellular fraction affected $(\mathrm{Fa}=1$ - the ratio of the drug-treated to the non-treated cell numbers). The plots were generated using the CompuSyn software, based on the cell viability data determined in the human BC cell lines MDA-MB-468, MDA-MB-231 and MCF-7 maintained in (A) cell cultures or (B) tumor spheroids. All the experiments were independently performed in triplicate.

Additional file 6 Figure S4: The cytotoxicity of the drug alone or in combination was assessed in the 3 different BC cell lines using Trypan Blue exclusion assay. (A) Representative images of different cancer cells after treatment for $72 \mathrm{~h}$ with Sal, Das, or the drug combination at their corresponding $\mathrm{IC}_{50}$ concentrations (Fig. 1c). Cells were incubated with Trypan Blue solution (0.4\%) for 3 min prior optical imaging. Scale bar is $50 \mu \mathrm{m}$. (B) Proportion of dead cell induced by the different drug treatments. Cells stained with Trypan Blue are considered as non-viable. Data were presented as mean \pm standard deviation (SD) and statistical differences were analyzed using Student's $t$-test $\left({ }^{*} P<0.05,{ }^{*} P<0.01\right)$.

Additional file 7 Figure S5: Representative microscopic images of the BC spheroids incubated for $72 \mathrm{~h}$ with the drugs alone or in combination at their corresponding $I C_{50}$ concentrations (Fig. 1h). Scale bar is $200 \mu \mathrm{m}$. (B) Evolution of the size of the spheroids following the different drug treatments. Four random diameters were measured on each picture.

Additional file 8 Figure S6: Effects of Sal and Das alone or in combination on apoptosis and necroptosis. The proportion of healthy, apoptotic, necrotic, and dead cells was measured by AnV binding and PI uptake using flow cytometry. (A) Plots of PI fluorescence versus AnV fluorescence. MDA-MB-468 cells were incubated with PBS (control), Sal $(0.5 \mu \mathrm{M})$, Das $(15 \mu \mathrm{M})$, or the drug combination for $72 \mathrm{~h}$ and then stained with AnV-FITC and PI for 10 min prior to FACS analysis. (B) Table showing the quantification of each cell populations following the different drug treatments. All the experiments were performed in triplicate.

Additional file 9 Figure S7: Neither Fer-1 nor Nec-1 could rescue the drug induced exposure of phosphatidylserine. (A) Investigation of the effects of ferrostatin-1 (Fer-1) and/or necrostatin-1 (Nec-1) (1 $\mu \mathrm{M}$ of inhibitor content) on the cytotoxicity of our drug combination. MDA-MB-468 cells were treated for $72 \mathrm{~h}$ with $\mathrm{S}+\mathrm{D}$ at different total drug contents (drug ratio fixed at 1:30) in the presence of Fer-1 and/or Nec-1 (1 $\mu \mathrm{M}$ of inhibitor content). The cell viability was evaluated using the CellTiter Glo Luminescent Assay. (B) Representative flow cytometry analysis showed that neither Fer-1 nor Nec-1 changed the proportion of apoptotic $\left(\mathrm{AnV}^{+} \mathrm{PI}^{-}\right)$/ dead $\left(\mathrm{AnV}^{+} \mathrm{Pl}^{+}\right)$cells induced by the drug combination. MDA-MB-468 cells were incubated with $\mathrm{S}+\mathrm{D}$ for $72 \mathrm{~h}$ in presence of (Fer-1) and/or (Nec-1) prior to staining with AnV-FITC and PI for FACS analysis. All the experiments were independently performed in triplicate.

Additional file 10 Figure S8: Tables summarizing the drug-induced changes in the expressions of targeted genes that are known to be regulated by (A) STAT3, (B) Wnt/ $\beta$-catenin, and (C) hedgehog pathways. The mRNA expression levels were retrieved from the RNA-seq data, and were presented as a $\log 2$ fold change relative to the control cells treated with PBS. The experiments were independently performed in quadruplicate. Note: N.S. = no significant change in the gene expression.

Additional file 11 Figure S9: (A) Bar graphs showing the 10 most significant canonical pathways that were modulated in MDA-MB-468 cells $24 \mathrm{~h}$ after treatment with Sal $(0.5 \mu \mathrm{M})$, Das $(15 \mu \mathrm{M})$, or the drug combination. (B) A table summarizing the changes in expression of the genes associated with the estrogen-mediated S-phase entry pathway. The experiments were performed in quadruplicate. N.S. = no significant change of the gene expression.

Additional file 12 Figure S10: Tables summarizing the differential expression of the genes associated with estrogen-mediated S-phase entry pathway in the BC cell line MDA-MB-468, after treatment with PBS, Sal $(0.5 \mu \mathrm{M})$, Das $(15 \mu \mathrm{M})$, or the drug combination for 24,48 , and $72 \mathrm{~h}$. Gene expression was determined using a RT-qPCR assay. All the experiments were performed in triplicate. Inset: N.S. = non-significant results; $A=a n-$ tagonistic; $\mathrm{Ad}=$ additive; and $\mathrm{S}=$ synergistic effect.

Additional file 13 Figure S11: Comparison of the RNA-seq and RTqPCR methods used to quantify the expression of the genes associated with the estrogen-mediated S-phase entry pathway in MDAMB-468 cells. Cells were treated with PBS, Sal $(0.5 \mu \mathrm{M})$, Das $(15 \mu \mathrm{M})$, or the drug combination for $72 \mathrm{~h}$ prior to the analysis. The differential gene expressions were presented as relative fold changes compared to the expression level of the same gene in cells treated with PBS (control). All the experiments were performed in triplicate.

Additional file 14 Figure S12: Tables summarizing the differential expression of the genes associated with estrogen-mediated S-phase entry pathway in human BC cell lines MDA-MB-468, MDA-MB-231, and MCF-7 $72 \mathrm{~h}$ after treatment with PBS, Sal $(0.5 \mu \mathrm{M})$, Das $(15 \mu \mathrm{M})$, or the drug combination. The gene expression was determined using a RT-qPCR assay. All the experiments were performed in triplicate. Inset: N.S. = non-significant results; $\mathrm{A}=$ antagonistic; $\mathrm{Ad}=$ additive; and $\mathrm{S}=$ synergistic effect.

Additional file 15 Figure S13: Original western blots used for Fig. 5 and Fig. S14. The blots were processed using Image Studio Lite 5.2 software The red boxes indicate the cropped regions used in the representative figures.

Additional file 16 Figure S14: (A) Western Blot analysis of ESR2 protein expression in MDA-MB-231 cells after exposure to the PBS, Sal $(0.5 \mu \mathrm{M})$, Das $(15 \mu \mathrm{M})$, or in combination for $72 \mathrm{~h}$. GAPDH was used as loading control. The blots were processed and cropped using Image Studio Lite 5.2 software. Full-length blots are available Fig. S13. (B) Graph bar showing the expression level of ESR2 protein. The relative protein expression levels were quantified using Image Studio software and normalized to the control cells treated with PBS. All the experiments were performed in triplicate. Data were presented as mean \pm standard deviation (SD) and statistical differences were calculated by Student's $t$-test $\left({ }^{*} P<0.05\right.$, ${ }^{* *} P<$ 0.01). (C) A flow cytometry graph showing an upregulation of ESR2 expression in response to Sal or the drug combination $(S+D)$ treatment. 
The MDA-MB-231 cells were treated with drugs alone (at the corresponding $\mathrm{IC}_{50}$ concentration) or 2-drugs combination prior to incubation with phycoerythrin-labeled anti-ESR2 for FACS analysis. (D) Representative fluorescence microscopic images showing Sal induced ESR2 in MDA-MB231 cells. Prior to imaging, the cells were incubated with phycoerythrinlabeled anti-ESR2 and DAPI for staining the ESR2 receptors (green) and the nucleus (blue), respectively. Scale bar is $60 \mu \mathrm{m}$.

Additional file 17 Figure S15: (A) Chemical structure of 4hydroxytamoxifen (Tamo). (B) Plots of the relative cell viability of MDAMB-468 cells $72 \mathrm{~h}$ after treatment with Das $(15 \mu \mathrm{M})$, Tamo $(1 \mu \mathrm{M})$, or the drug combination $(D+T)$.

Additional file 18 Figure S16: Sal and Das together synergistically inhibited the BRCA1 pathway in a MDA-MB-468 cell line. A table summarizing the differential gene expression of cells treated with Sal $(0.5 \mu \mathrm{M})$ or Das $(15 \mu \mathrm{M})$, or the drug combination. The experiments were performed in quadruplicate. N.S. = no significant change of the gene expression.

\section{Abbreviations}

AKT: Protein kinase B; ALDH1: Aldehyde dehydrogenase 1; BC: Breast cancer; BCL: Binary base call; CCND1: Cyclin D1; CCNE2: Cyclin E2; CDC: Cell division cycle; CDK: Cyclin-dependent kinase; CDNA: Complementary deoxyribonucleic acid; Cl: Combination index; CSCs: Cancer stem cells; CYT387: Momelotinib; DAPI: 4',6-Diamidino-2-phenylindole; Das: Dasatinib, DCF-DA: 2',7'-Dichlorofluorescein diacetate; DNA: Deoxyribonucleic acid; Dox: Doxorubicin; E2F: E2F transcription factor; EGFR: Epidermal growth factor receptor; EGR: Early growth response; ER: Estrogen receptor; ESR2: Estrogen receptor $\beta$; FACS: Fluorescence-activated cell sorting; FBS: Fetal bovine serum; FITC: Fluorescein isothiocyanate; FPKM: Fragments per kilobase of exon model per million; GAPDH: Glyceraldehyde 3-phosphate dehydrogenase; GEO: Gene expression omnibus; GFP: Green fluorescent protein; HER2: Human epidermal growth factor receptor $2 ; I_{5}$ : Half maximal inhibitory concentration; IPA: Ingenuity pathway analysis software; iROS: Intracellular reactive oxygen species; JAK: Janus kinase; JNK: Jun aminoterminal kinase; MAPK: Mitogen-activated protein kinase; M-MLV: Moloney murine leukemia virus; mRNA: Messenger ribonucleic acid;

mTOR: Mammalian target of rapamycin; NCBI: National center for biotechnology information; NCL: Nucleolin gene; N.S.: non-significant; $P_{\text {adj: }}$ Adjusted $p$ value; PBS: Phosphate buffered saline; PI: Propidium iodide; PI3K: Phosphoinositide 3-kinase; RBL1: Retinoblastoma-like 1; RNAseq: Ribonucleic acid sequencing; RT-qPCR: Reverse transcription-quantitative polymerase chain reaction; S + D: Salinomycin + dasatinib; Sal: Salinomycin; SD: Standard deviation; shRNA: Small hairpin ribonucleic acid; SKP: S-phase kinase associated protein; STAT: Signal transducer and activator of transcription; Tamo: 4-Hydroxytamoxifen; TBST: Tris buffer saline containing Tween; TNBC: Triple negative breast cancer

\section{Acknowledgements}

The authors would like to thank the Weill Cornell Medicine Genomics Resources Core Facility, and particularly Dr. Adrian Tan, for performing the RNA-sequencing analyses and the bioinformatics processing of the data. The authors also thank Jaclyn McCloskey for her valuable assistance with the RTqPCR experiments, and Cynthia Fox for proof-reading the manuscript.

\section{Authors' contributions}

VB: Conceptualization, visualization, methodology, formal analysis, data curation, and writing - original draft and review/editing. AV and SA: Methodology, resources, writing - review/editing. BL: Funding acquisition, conceptualization, visualization, project administration, writing - original draft and review/editing. All the authors read and approved the manuscript.

\section{Funding}

The research work was supported in part by National Cancer Institute (Grant Nos. R03 CA219718 and R01 CA222802 to B.L.), and Radiology Department, WCM.

\section{Availability of data and materials}

The raw RNA sequencing dataset reported in this paper is available in the Gene Expression Omnibus (GEO) database using the accession number GSE135514 and following the link:
https://www.ncbi.nlm.nih.gov/geo/query/acc.cgi?acc=GSE135514. All other resources related to this research work are available upon reasonable request to the lead contact Benedict Law (sbl2004@med.cornell.edu).

\section{Ethics approval and consent to participate}

Not applicable.

\section{Consent for publication}

Not applicable.

\section{Competing interests}

The authors declare no competing interests.

\section{Author details}

${ }^{1}$ Molecular Imaging Innovations Institute, Department of Radiology, Weill Cornell Medicine, New York, NY, USA. ${ }^{2}$ Department of Biochemistry, Weill Cornell Medicine, New York, NY, USA. ${ }^{3}$ Lead contact, New York, USA.

Received: 27 February 2020 Accepted: 2 July 2020

Published online: 16 July 2020

\section{References}

1. Siegel RL, Miller KD, Jemal A. Cancer statistics, 2019. Ca-Cancer J Clin. 2019; 69(1):7-34. https://doi.org/10.3322/caac.21551.

2. von Minckwitz G, Schneeweiss A, Loibl S, Salat C, Denkert C, Rezai M, Blohmer JU, Jackisch C, Paepke S, Gerber B, Zahm DM, Kummel S, Eidtmann H, Klare P, Huober J, Costa S, Tesch H, Hanusch C, Hilfrich J, Khandan F, Fasching PA, Sinn BV, Engels K, Mehta K, Nekljudova V, Untch M. Neoadjuvant carboplatin in patients with triple-negative and HER2-positive early breast cancer (GeparSixto; GBG 66): a randomised phase 2 trial. Lancet Oncol. 2014;15(7):747-56. https://doi.org/10.1016/S1470-2045(14)70160-3.

3. Sikov WM, Berry DA, Perou CM, Singh B, Cirrincione CT, Tolaney SM, Kuzma CS, Pluard TJ, Somlo G, Port ER, Golshan M, Bellon JR, Collyar D, Hahn OM, Carey LA, Hudis CA, Winer EP. Impact of the addition of carboplatin and/or bevacizumab to neoadjuvant once-per-week paclitaxel followed by dosedense doxorubicin and cyclophosphamide on pathologic complete response rates in stage II to III triple-negative breast cancer: CALGB 40603 (Alliance). J Clin Oncol. 2015;33(1):13-21. https://doi.org/10.1200/JCO.2014. 57.0572.

4. Qi WX, Tang LN, He AN, Shen Z, Yao Y. Comparison between doublet agents versus single agent in metastatic breast cancer patients previously treated with an anthracycline and a taxane: a meta-analysis of four phase III trials. Breast. 2013;22(3):314-9. https://doi.org/10.1016/j.breast.2012.07.014.

5. Nunes T, Hamdan D, Leboeuf C, El Bouchtaoui M, Gapihan G, Nguyen TT, Meles S, Angeli E, Ratajczak P, Lu H, Di Benedetto M, Bousquet G, Janin A. Targeting Cancer stem cells to overcome Chemoresistance. Int J Mol Sci. 2018;19(12). https://doi.org/10.3390/ijms19124036.

6. Chou TC. Theoretical basis, experimental design, and computerized simulation of synergism and antagonism in drug-combination studies (vol 58, pg 621, 2006). Pharmacol Rev. 2007;59(1):124. https://doi.org/10.1124/pr. 58.3.10.

7. Gupta PB, Onder TT, Jiang G, Tao K, Kuperwasser C, Weinberg RA, Lander ES Identification of selective inhibitors of cancer stem cells by high-throughput screening. Cell. 2009;138(4):645-59. https://doi.org/10.1016/j.cell.2009.06.034.

8. Huczynski A, Janczak J, Antoszczak M, Wietrzyk J, Maj E, Brzezinski B. Antiproliferative activity of salinomycin and its derivatives. Bioorg Med Chem Lett. 2012;22(23):7146-50. https://doi.org/10.1016/j.bmcl.2012.09.068.

9. Huczynski A. Polyether ionophores-promising bioactive molecules for cancer therapy. Bioorg Med Chem Lett. 2012;22(23):7002-10. https://doi.org/ 10.1016/j.bmcl.2012.09.046.

10. Verdoodt B, Vogt M, Schmitz I, Liffers ST, Tannapfel A, Mirmohammadsadegh A. Salinomycin induces autophagy in colon and breast cancer cells with concomitant generation of reactive oxygen species. PLoS One. 2012;7(9):e44132. https://doi.org/10.1371/journal.pone.0044132.

11. Takebe N, Miele L, Harris PJ, Jeong W, Bando H, Kahn M, Yang SX, Ivy SP. Targeting notch, hedgehog, and Wnt pathways in cancer stem cells: clinical update. Nat Rev Clin Oncol. 2015;12(8):445-64. https://doi.org/10.1038/ nrclinonc.2015.61.

12. Galoczova M, Coates $P$, Vojtesek B. STAT3, stem cells, cancer stem cells and p63. Cell Mol Biol Lett. 2018;23:12. https://doi.org/10.1186/s11658-018-0078-0. 
13. Koo KH, Kim H, Bae YK, Kim K, Park BK, Lee CH, Kim YN. Salinomycin induces cell death via inactivation of Stat3 and downregulation of Skp2. Cell Death Dis. 2013;4:e693. https://doi.org/10.1038/cddis.2013.223.

14. Mao J, Fan S, Ma W, Fan P, Wang B, Zhang J, Wang H, Tang B, Zhang Q, Yu $X$, Wang L, Song B, Li L. Roles of Wnt/beta-catenin signaling in the gastric cancer stem cells proliferation and salinomycin treatment. Cell Death Dis. 2014;5:e1039. https://doi.org/10.1038/cddis.2013.515.

15. Klose J, Eissele J, Volz C, Schmitt S, Ritter A, Ying S, Schmidt T, Heger U, Schneider M, Ulrich A. Salinomycin inhibits metastatic colorectal cancer growth and interferes with Wnt/beta-catenin signaling in CD133(+) human colorectal cancer cells. BMC Cancer. 2016;16(1):896. https:/doi.org/10.1186/ s12885-016-2879-8.

16. Fu YZ, Yan YY, He M, Xiao QH, Yao WF, Zhao L, Wu HZ, Yu ZJ, Zhou MY, Lv MT, Zhang SS, Chen JJ, Wei MJ. Salinomycin induces selective cytotoxicity to MCF-7 mammosphere cells through targeting the hedgehog signaling pathway. Oncology Rep. 2016;35(2):912-22. https://doi.org/10.3892/or.2015. 4434.

17. An H, Kim JY, Oh E, Lee N, Cho Y, Seo JH. Salinomycin promotes Anoikis and decreases the CD44+/CD24- stem-like population via inhibition of STAT3 activation in MDA-MB-231 cells. PLoS One. 2015;10(11):e0141919. https://doi.org/10.1371/journal.pone.0141919.

18. Chung SS, Adekoya D, Enenmoh I, Clarke O, Wang P, Sarkyssian M, Wu Y, Vadgama JV. Salinomycin abolished STAT3 and STAT1 interactions and reduced telomerase activity in colorectal Cancer cells. Anticancer Res. 2017; 37(2):445-53. https://doi.org/10.21873/anticanres.11336.

19. Kim JH, Chae M, Kim WK, Kim YJ, Kang HS, Kim HS, Yoon S. Salinomycin sensitizes cancer cells to the effects of doxorubicin and etoposide treatment by increasing DNA damage and reducing p21 protein. $\mathrm{Br} J$ Pharmacol. 2011;162(3):773-84. https://doi.org/10.1111/j.1476-5381.2010. 01089.x.

20. Kim WK, Kim JH, Yoon K, Kim S, Ro J, Kang HS, Yoon S. Salinomycin, a pglycoprotein inhibitor, sensitizes radiation-treated cancer cells by increasing DNA damage and inducing G2 arrest. Investig New Drugs. 2012;30(4):13118. https://doi.org/10.1007/s10637-011-9685-6.

21. Kim JH, Yoo HI, Kang HS, Ro J, Yoon S. Salinomycin sensitizes antimitotic drugs-treated cancer cells by increasing apoptosis via the prevention of $\mathrm{G} 2$ arrest. Biochem Biophys Res Comm. 2012;418(1):98-103. https://doi.org/10. 1016/j.bbrc.2011.12.141.

22. Scher KS, Somlo G. Dasatinib : a novel therapy for breast cancer? Expert Opin Investig Drugs. 2013;22(6):795-801. https://doi.org/10.1517/13543784. 2013.793308.

23. Nautiyal J, Majumder P, Patel BB, Lee FY, Majumdar AP. Src inhibitor dasatinib inhibits growth of breast cancer cells by modulating EGFR signaling. Cancer Lett. 2009;283(2):143-51. https://doi.org/10.1016/j.canlet. 2009.03.035

24. Mayer EL, Krop IE. Advances in targeting SRC in the treatment of breast cancer and other solid malignancies. Clin Cancer Res. 2010;16(14):3526-32. https://doi.org/10.1158/1078-0432.CCR-09-1834.

25. Hiscox S, Nicholson RI. Src inhibitors in breast cancer therapy. Expert Opin Ther Targets. 2008;12(6):757-67. https://doi.org/10.1517/14728222.12.6.757.

26. Kurebayashi J, Kanomata N, Moriya T, Kozuka Y, Watanabe M, Sonoo H. Preferential antitumor effect of the Src inhibitor dasatinib associated with a decreased proportion of aldehyde dehydrogenase 1-positive cells in breast cancer cells of the basal B subtype. BMC Cancer. 2010;10:568. https://doi. org/10.1186/1471-2407-10-568.

27. Tzeng YT, Liu PF, Li JY, Liu LF, Kuo SY, Hsieh CW, Lee CH, Wu CH, Hsiao M, Chang HT, Shu CW. Kinome-wide siRNA screening identifies Src-enhanced resistance of chemotherapeutic drugs in triple-negative breast Cancer cells. Front Pharmacol. 2018;9:1285. https://doi.org/10.3389/fphar.2018.01285.

28. Ivascu A, Kubbies M. Rapid generation of single-tumor spheroids for highthroughput cell function and toxicity analysis. J Biomol Screen. 2006;11(8): 922-32. https://doi.org/10.1177/1087057106292763.

29. Dobin A, Davis CA, Schlesinger F, Drenkow J, Zaleski C, Jha S, Batut P, Chaisson M, Gingeras TR. STAR: ultrafast universal RNA-seq aligner. Bioinformatics. 2013; 29(1):15-21. https://doi.org/10.1093/bioinformatics/bts635.

30. Trapnell C, Hendrickson DG, Sauvageau M, Goff L, Rinn JL, Pachter L. Differential analysis of gene regulation at transcript resolution with RNA-seq. Nature Biotech. 2013;31(1):46. https://doi.org/10.1038/nbt.2450.

31. Love MI, Huber W, Anders S (2014) Moderated estimation of fold change and dispersion for RNA-seq data with DESeq2. Genome Biol 15 (12). Doi: ARTN 550. https://doi.org/10.1186/s13059-014-0550-8.
32. Schmittgen TD, Livak KJ. Analyzing real-time PCR data by the comparative C(T) method. Nat Protoc. 2008;3(6):1101-8. https://doi.org/10.1186/s13059014-0550-8.

33. Chou TC. Theoretical basis, experimental design, and computerized simulation of synergism and antagonism in drug combination studies. Pharmacol Rev. 2006;58(3):621-81. https://doi.org/10.1124/pr.58.3.10.

34. Finn RS, Dering J, Ginther C, Wilson CA, Glaspy P, Tchekmedyian N, Slamon DJ. Dasatinib, an orally active small molecule inhibitor of both the src and abl kinases, selectively inhibits growth of basal-type/"triple-negative" breast cancer cell lines growing in vitro. Breast Cancer Res Treat. 2007;105(3):31926. https://doi.org/10.1007/s10549-006-9463-x.

35. Tardi PG, Dos Santos N, Harasym TO, Johnstone SA, Zisman N, Tsang AW, Bermudes DG, Mayer LD. Drug ratio-dependent antitumor activity of irinotecan and cisplatin combinations in vitro and in vivo. Mol Cancer Ther. 2009:8(8):2266-75. https://doi.org/10.1158/1535-7163.MCT-09-0243.

36. Tsakalozou E, Eckman AM, Bae Y. Combination effects of docetaxel and doxorubicin in hormone-refractory prostate cancer cells. Biochem Res Int. 2012;2012:832059. https://doi.org/10.1155/2012/832059.

37. Fonseca NA, Gomes-da-Silva LC, Moura V, Simoes S, Moreira JN. Simultaneous active intracellular delivery of doxorubicin and C6-ceramide shifts the additive/ antagonistic drug interaction of non-encapsulated combination. J Control Release. 2014;196:122-31. https://doi.org/10.1016/j.jconrel.2014.09.024.

38. Howes AL, Richardson RD, Finlay D, Vuori K. 3-dimensional culture systems for anti-cancer compound profiling and high-throughput screening reveal increases in EGFR inhibitor-mediated cytotoxicity compared to monolayer culture systems. PLoS One. 2014;9(9):e108283. https://doi.org/10.1371/ journal.pone.0108283.

39. Mehta G, Hsiao AY, Ingram M, Luker GD, Takayama S. Opportunities and challenges for use of tumor spheroids as models to test drug delivery and efficacy. J Control Release. 2012;164(2):192-204. https://doi.org/10.1016/j. jconrel.2012.04.045.

40. Bryce NS, Zhang JZ, Whan RM, Yamamoto N, Hambley TW. Accumulation of an anthraquinone and its platinum complexes in cancer cell spheroids: the effect of charge on drug distribution in solid tumour models. Chem Commun (Camb). 2009;19:2673-5. https://doi.org/10.1039/b902415h.

41. Bellat V, Ting R, Southard TL, Vahdat L, Molina H, Fernandez J, Aras O, Stokol T, Law B. Functional peptide Nanofibers with unique tumor targeting and enzyme-induced local retention properties. Adv Funct Mater. 2018;28(44). https://doi.org/10.1002/adfm.201803969.

42. Yu SN, Kim SH, Kim KY, Ji JH, Seo YK, Yu HS, Ahn SC. Salinomycin induces endoplasmic reticulum stressmediated autophagy and apoptosis through generation of reactive oxygen species in human glioma U87MG cells. Oncol Rep. 2017;37(6):3321-8. https://doi.org/10.3892/or.2017.5615.

43. Kim KY, Park KI, Kim SH, Yu SN, Lee D, Kim YW, Noh KT, Ma JY, Seo YK, Ahn SC. Salinomycin induces reactive oxygen species and apoptosis in aggressive breast Cancer cells as mediated with regulation of autophagy. Anticancer Res. 2017:37(4):1747-58. https://doi.org/10.21873/anticanres.11507.

44. Kim KY, Park KI, Kim SH, Yu SN, Park SG, Kim YW, Seo YK, Ma JY, Ahn SC. Inhibition of autophagy promotes Salinomycin-induced apoptosis via reactive oxygen species-mediated PI3K/AKT/mTOR and ERK/p38 MAPKdependent signaling in human prostate Cancer cells. Int J Mol Sci. 2017; 18(5). https://doi.org/10.3390/ijms18051088.

45. Wu Y, Zhang D, Wu B, Quan Y, Liu D, Li Y, Zhang X. Synergistic activity of an antimetabolite drug and tyrosine kinase inhibitors against breast Cancer cells. Chem Pharm Bull (Tokyo). 2017;65(8):768-75. https://doi.org/10.1248/ cpb.c17-00261.

46. Lu D, Choi MY, Yu J, Castro JE, Kipps TJ, Carson DA. Salinomycin inhibits Wnt signaling and selectively induces apoptosis in chronic lymphocytic leukemia cells. Proc Natl Acad Sci U S A. 2011;108(32):13253-7. https://doi. org/10.1073/pnas.1110431108.

47. Zhou S, Wang F, Zhang Y, Johnson MR, Qian S, Wu M, Wu E. Salinomycin suppresses PDGFRbeta, MYC, and notch signaling in human Medulloblastoma. Aust J Pharmacol Ther. 2014;2(3):1020. Pmcid: PMC4251667..

48. Zhao SJ, Wang XJ, Wu QJ, Liu C, Li DW, Fu XT, Zhang HF, Shao LR, Sun JY, Sun BL, Zhai J, Fan CD. Induction of G1 cell cycle arrest in human Glioma cells by Salinomycin through triggering ROS-mediated DNA damage in vitro and in vivo. Neurochem Res. 2017;42(4):997-1005. https://doi.org/10. 1007/s11064-016-2132-5.

49. Mukhopadhyay UK, Oturkar CC, Adams C, Wickramasekera N, Bansal S, Medisetty R, Miller A, Swetzig WM, Silwal-Pandit L, Borresen-Dale AL, 
Creighton CJ, Park JH, Konduri SD, Mukhopadhyay A, Caradori A, Omilian A, Bshara W, Kaipparettu BA, Das GM. TP53 status as a determinant of proversus anti-tumorigenic effects of estrogen receptor-beta in breast Cancer. J Natl Cancer Inst. 2019. https://doi.org/10.1093/jnci/djz051.

50. Lue HW, Cole B, Rao SA, Podolak J, Van Gaest A, King C, Eide CA, Wilmot B, Xue C, Spellman PT, Heiser LM, Tyner JW, Thomas GV. Src and STAT3 inhibitors synergize to promote tumor inhibition in renal cell carcinoma. Oncotarget. 2015;6(42):44675-87. https://doi.org/10.18632/oncotarget.5971.

51. Chien W, Sudo M, Ding LW, Sun QY, Wuensche P, Lee KL, Hattori N, Garg M, Xu L, Zheng Y, Gery S, Wongphayak S, Yang H, Baloglu E, Shacham S, Kauffman M, Mori S, Koeffler HP. Functional genome-wide screening identifies targets and pathways sensitizing pancreatic Cancer cells to Dasatinib. J Cancer. 2018;9(24):4762-73. https://doi.org/10.7150/jca.25138.

52. Cousins EM, Goldfarb D, Yan F, Roques J, Darr D, Johnson GL, Major MB. Competitive kinase enrichment proteomics reveals that Abemaciclib inhibits GSK3beta and Activates WNT signaling. Mol Cancer Res: MCR. 2018;16(2): 333-44. https://doi.org/10.1158/1541-7786.MCR-17-0468.

53. Niwa AM, Marques LA, Semprebon SC, Sartori D, Ribeiro LR, Mantovani MS. Salinomycin efficiency assessment in non-tumor (HB4a) and tumor (MCF-7) human breast cells. Naunyn Schmiedeberg's Arch Pharmacol. 2016;389(6): 557-71. https://doi.org/10.1007/s00210-016-1225-7.

54. Attwooll C, Lazzerini Denchi E, Helin K. The E2F family: specific functions and overlapping interests. EMBO J. 2004;23(24):4709-16. https://doi.org/10. 1038/sj.emboj.7600481.

55. Chen $\mathrm{HZ}$, Tsai SY, Leone G. Emerging roles of E2Fs in cancer: an exit from cell cycle control. Nat Rev Cancer. 2009;9(11):785-97. https://doi.org/10. 1038/nrc2696.

56. Thwaites MJ, Cecchini MJ, Passos DT, Welch I, Dick FA. Interchangeable roles for E2F transcriptional repression by the retinoblastoma protein and p27KIP1-Cyclin-dependent kinase regulation in cell cycle control and tumor suppression. Mol Cell Biol. 2017;37(2). https://doi.org/10.1128/MCB.00561-16.

57. Austin D, Hamilton N, Elshimali Y, Pietras R, Wu Y, Vadgama J. Estrogen receptor-beta is a potential target for triple negative breast cancer treatment. Oncotarget. 2018;9(74):33912-30. https://doi.org/10.18632/ oncotarget.26089.

58. Novelli F, Milella M, Melucci E, Di Benedetto A, Sperduti I, Perrone-Donnorso R, Perracchio L, Venturo I, Nistico C, Fabi A, Buglioni S, Natali PG, Mottolese M. A divergent role for estrogen receptor-beta in node-positive and nodenegative breast cancer classified according to molecular subtypes: an observational prospective study. Breast Cancer Res. 2008;10(5):R74. https:// doi.org/10.1186/bcr2139.

59. Lazennec G, Bresson D, Lucas A, Chauveau C, Vignon F. ER beta inhibits proliferation and invasion of breast cancer cells. Endocrinology. 2001;142(9): 4120-30. https://doi.org/10.1210/endo.142.9.8395.

60. Schuler-Toprak S, Haring J, Inwald EC, Moehle C, Ortmann O, Treeck O. Agonists and knockdown of estrogen receptor beta differentially affect invasion of triple-negative breast cancer cells in vitro. BMC Cancer. 2016 16(1):951. https://doi.org/10.1186/s12885-016-2973-y.

61. Bado I, Nikolos F, Rajapaksa G, Gustafsson JA, Thomas C. ERbeta decreases the invasiveness of triple-negative breast cancer cells by regulating mutant p53 oncogenic function. Oncotarget. 2016;7(12):13599-611. https://doi.org/ 10.18632/oncotarget.7300.

62. Hamilton N, Marquez-Garban D, Mah V, Fernando G, Elshimali Y, Garban H, Elashoff D, Vadgama J, Goodglick L, Pietras R. Biologic roles of estrogen receptor-beta and insulin-like growth factor-2 in triple-negative breast cancer. Biomed Res Int. 2015;2015:925703. https://doi.org/10.1155/2015/ 925703.

63. Jensen EV, Cheng G, Palmieri C, Saji S, Makela S, Van Noorden S, Wahlstrom T, Warner M, Coombes RC, Gustafsson JA. Estrogen receptors and proliferation markers in primary and recurrent breast cancer. Proc Natl Acad Sci U S A. 2001;98(26):15197-202. https://doi.org/10.1073/pnas.211556298.

64. Hopp TA, Weiss HL, Parra IS, Cui Y, Osborne CK, Fuqua SA. Low levels of estrogen receptor beta protein predict resistance to tamoxifen therapy in breast cancer. Clin Cancer Res. 2004;10(22):7490-9. https://doi.org/10.1158/ 1078-0432.CCR-04-1114.

65. Esslimani-Sahla M, Simony-Lafontaine J, Kramar A, Lavaill R, Mollevi C, Warner M, Gustafsson JA, Rochefort H. Estrogen receptor beta (ER beta) level but not its ER beta $\mathrm{cx}$ variant helps to predict tamoxifen resistance in breast cancer. Clin Cancer Res. 2004;10(17):5769-76. https://doi.org/10.1158/ 1078-0432.CCR-04-0389.
66. Espinal-Enriquez J, Fresno C, Anda-Jauregui G, Hernandez-Lemus E. RNA-Seq based genome-wide analysis reveals loss of inter-chromosomal regulation in breast cancer. Sci Rep. 2017;7(1):1760. https://doi.org/10.1038/541598-01701314-1.

67. Shin SY, Kim CG, Lee YH. Egr-1 regulates the transcription of the BRCA1 gene by etoposide. BMB Rep. 2013;46(2):92-6. https://doi.org/10.5483/ bmbrep.2013.46.2.202.

68. Wang B. BRCA1 tumor suppressor network: focusing on its tail. Cell Biosci. 2012;2(1):6. https://doi.org/10.1186/2045-3701-2-6.

69. Wu LC, Wang ZW, Tsan JT, Spillman MA, Phung A, Xu XL, Yang MC, Hwang LY, Bowcock AM, Baer R. Identification of a RING protein that can interact in vivo with the BRCA1 gene product. Nat Genet. 1996;14(4):430-40. https:// doi.org/10.1038/ng1296-430.

70. Wang FF, Zhou S, Qi D, Xiang SH, Wong ET, Wang XJ, Fonkem E, Hsieh TC, Yang JH, Kirmani B, Shabb JB, Wu JM, Wu M, Huang JSH, Yu WH, Wu EX. Nucleolin is a functional binding protein for Salinomycin in neuroblastoma stem cells. J Amer Chem Soc. 2019;141(8):3613-22. https://doi.org/10.1021/ jacs.8b12872.

71. Guerin M, Goncalves A, Toiron Y, Baudelet E, Audebert S, Boyer JB, Borg JP, Camoin L. How may targeted proteomics complement genomic data in breast cancer? Expert Rev Proteomic. 2017;14(1):43-54. https://doi.org/10. 1080/14789450.2017.1256776.

72. Abdel-Fatah TMA, Agarwal D, Liu DX, Russell R, Rueda OM, Liu K, Xu B, Moseley PM, Green AR, Pockley AG, Rees RC, Caldas C, Ellis IO, Ball GR, Chan SYT. SPAG5 as a prognostic biomarker and chemotherapy sensitivity predictor in breast cancer: a retrospective, integrated genomic, transcriptomic, and protein analysis. Lancet Oncol. 2016;17(7):1004-18. https://doi.org/10.1016/S1470-2045(16)00174-1.

73. Cheng FX, Zhao JF, Hanker AB, Brewer MR, Arteaga CL, Zhao ZM. Transcriptome- and proteome-oriented identification of dysregulated elF4G, STAT3, and hippo pathways altered by PIK3CA (H1047R) in HER2/ER-positive breast cancer. Breast Cancer Res Tr. 2016;160(3):457-74. https://doi.org/10. 1007/s10549-016-4011-9.

\section{Publisher's Note}

Springer Nature remains neutral with regard to jurisdictional claims in published maps and institutional affiliations.

Ready to submit your research? Choose BMC and benefit from:

- fast, convenient online submission

- thorough peer review by experienced researchers in your field

- rapid publication on acceptance

- support for research data, including large and complex data types

- gold Open Access which fosters wider collaboration and increased citations

- maximum visibility for your research: over $100 \mathrm{M}$ website views per year

At $\mathrm{BMC}$, research is always in progress.

Learn more biomedcentral.com/submissions 